\title{
“Kullanıcı Üretimi" Kolektif Hafıza: Adalet Yürüyüşü Örneği
}

\author{
Gülşah Başlar
}

araştırma görevlisi doktor, marmara üniversitesi iletişim fakültesi radyo tv ve sinema bölümü

gulsahsaner@gmail.com

\section{Abstract March \\ "User Generated" Collective Memory: The Case of Justice}

The process of constructing collective memory, based on the sharing of common experiences has undergone a major change with the inclusion of new media users in content production. In this context, users share their experiences, opinions, comments or information about a recent topic on the internet; so individual memories began to gain public or semi-public character. Thus, it has been noticed that a "user generated" collective memory has been formed on the internet. This study aims to understand the characteristics of the collective memory constructed in the new media and how the new media affected this change. The research focuses on the collective memory formed in Ekşi Sözlük, where the users open up topics related to the recent events and share their experiences, knowledge and opinions. The construction process and characteristics of collective memory in this area is investigated through the case of "Justice March". The contents produced by the users about this event are analyzed by using the content analysis method. As a result of the research, it has been revealed that the collective memory which is based on user generated content is composed of mainly interpretive, short and fragmented information.

Bu makaleye referans vermek için: Başlar G., (2018). "Kullanıcı Üretimi” Kolektif Hafıza: Adalet Yürüyüşü Örneği. Galatasaray Üniversitesi Ileti-ş-im Dergisi, 28, 143-175. DOI: 10.16878/gsuilet.436041 
keywords: collective memory, user generated content, new media, Justice March

\section{Résumé}

\section{Mémoire collective "produit par l'utilisateur": le cas de la marche pour la justice}

Le processus de construction de la mémoire collective, basé sur le partage d'expériences communes, a subi un changement majeur avec l'inclusion de l'utilisateur des nouveaux médias dans la production de contenu. Dans ce contexte, les utilisateurs partagent leurs expériences, opinions, témoignages ou informations sur l'Internet. Les mémoires individuelles ont commencé à acquérir un caractère public ou semi-public. Ainsi, on voit qu'une mémoire collective est construite sur I'Internet en tant que la "production d'utilisateur". Cette étude vise à comprendre les caractéristiques de la mémoire collective construite dans les nouveaux médias et comment les nouveaux médias apportent des changements dans ce processus. Dans ce travail, la mémoire collective produite sur Ekşi Sözlük où les utilisateurs partagent leurs expériences, connaissances et opinions en abordant des sujets liés aux événements actuels est pris en compte. Le processus de production et les caractéristiques de la mémoire collective ont été examinés par l'étude de cas "la marche pour la justice". Les contenus produits par les utilisateurs ont été analysés par la méthode de l'analyse de contenu. En conclusion, nous avons constaté que la mémoire collective basée sur le contenu est produite par l'utilisateur et qu'elle est composée d'informations en grande partie interprétatives, courtes et fragmentées.

mots-clés: mémoire collective, contenu produit par l'utilisateur, les nouveaux médias, la marche pour la justice 
Öz

Ortak deneyimlerin paylaşılmasına dayanan kolektif hafızanın inşa süreci, yeni medyada kullanıcının içerik üretimine katılmasıyla birlikte önemli bir değişim geçirmiştir. Bu kapsamda kullanıcılar gündemdeki bir konuyla ilgili kendi deneyim, görüş, tanıklık ya da bilgilerini internet üzerinden paylaşmaya, bireysel hafızalar kamusal ya da yarı kamusal bir nitelik kazanmaya başlamıştır. Böylece internette "kullanıcı üretimi" bir kolektif hafızanın oluşmakta olduğu görülmektedir. Bu çalışmada da yeni medyada inşa edilen kolektif hafızanın özelliklerinin ve yeni medyanın bu süreçte nasıl bir değişim getirdiğinin anlaşılması amaçlanmıştır. Araştırma bölümünde kullanıcıların gündemdeki olaylarla ilgili başılılar açıp kendi deneyim, bilgi ve görüşlerini paylaştığı Ekşi Sözlük'te oluşan kolektif hafızaya odaklanılmıştır. Buradaki kolektif hafızanın inşa süreci ve özellikleri "Adalet Yürüyüşü" örnek olayı seçilerek, kullanıcıların ürettiği içerikler içerik analizi yöntemi kullanılarak incelenmiştir. Araştırma sonucunda kullanıcı üretimi içeriğe dayalı olarak oluşan kolektif hafızanın yorum ağırlıkı, kısa ve parçalı bilgilerden oluştuğu görülmüştür.

anahtar kelimeler: kolektif hafıza, kullanıcı üretimi içerik, yeni medya, Adalet Yürüyüşü 


\section{Giriş}

Hafızanın oluşumu, saklanması ve geleceğe aktarılması psikoloji, felsefe, sosyoloji, siyaset bilimi ve iletişim gibi pek çok disiplinde incelenen çalışma alanlarından biridir.

Felsefe alanında Antik Yunan'dan itibaren "imgeleri zihne sokma becerisi eğretilemesi" olarak görülmüş olan hafıza, "geçmişin şimdi tarafından tamamen geri kazanıması" amacını içerisinde barındıı (Barash, 2007, s. 12-13). Hatırlama ve unutma edimlerine dayanan hafiza temel olarak bireysel bir fenomen (Olick, 2008, s. 152) olsa da toplumsal, psikolojik ve tarihi etkilerden bağımsız olmayan bir bilgi kodlama, depolama ve gerektiğinde stratejik olarak bulup getirme sürecidir. Dolayısıyla hafıza her zaman seçicidir ve çarpıtma eğilimine sahiptir (Schudson, 2007, s. 181). Bergson da bireyin algııının geçmiş deneyimlerine bağlı olarak seçici olduğunu ve hafızanın bu şekilde oluştuğunu vurgular (aktaran GardeHansen, 2011, s. 20). Bu bağlamda hafıza ve ona bağlı olarak unutma ve hatırlama kişisel, kültürel, politik, psikolojik, toplumsal pek çok etmene bağlı olarak oluşur. Garde-Hansen hafızanın bu çok yönlülüğünü şöyle açıklar:

Hafıza, duygularımız gibi, birlikte yaşadığımız bir şeydir, ancak sadece kafalarımızın ve bedenlerimizin içinde değildir. (...) Hafızalarımızı ifade eder, temsil eder ve hissederiz- ve hem hafızamızı hem de duygularımızı; dünyadaki varlığımızın girift zincirlerini oluşturan kişisel, kültürel, psikolojik, nörolojik, politik, dini, sosyal ve etnik platoları üzerinden yansıtırız (Garde-Hansen, 2011, s. 14).

Hafıza üzerine çalışırken hafıza olgusunun belli bir seçime dayalı olarak kurulduğunu ve toplumsal, politik, kültürel pek çok etkiye açık şekilde oluştuğunu akılda tutmak gerekir. Huyssen'in de belirttiği gibi hafıza "her zaman geçici, herkesin bildiği gibi güvenilmez ve unutma tarafından lanetlenmiş" niteliktedir. Hafıza ayrıca aktif ve canlıdır; toplumsal yaşamın içerisinde somutlaşarak açığa çıkar (Huyssen, 2003, s. 28). Assmann hafıza ve toplum ilişkisini şöyle açıklar: "Hafıza (...) biz insanların gruplar ve topluluklar haline yaşamasını mümkün kılar; gruplar ve topluluklar halinde yaşamak ise bir hafıza inşa etmemize olanak tanır." (2011, s. 23). Toplum ile hafıza arasındaki bu ilişki kolektif hafıza kavramının temelini oluşturur.

Halbwachs öncülleri Durkheim ${ }^{1}$ ve Bergson'dan² etkilenerek, hafıza

1 Durkheim toplumun birey üzerindeki etkisini ve toplumun onu oluşturan parçalardan fazlasını ifade ettiğini kolektif bilinç ve kolektif temsil kavramları üzerinden açıklamıştır (Simpson, 2005, s. XI). Ona göre kolektif yaşam temsillerden oluşur. Kolektif temsiller ise bireysel temsillerden oluşsa da bunların toplamı gibi düşünülemez ve tamamen farklı bir niteliğe sahiptir. Bireysel bilinçler biraraya gelerek, birbirini karşılıklı etkileyerek toplumsal bilinç şeklinde yeni bir gerçeklik ortaya koyar. Bu açıdan kolektifliğin kendine özgü düşünme ve hissetme yolları vardır (Durkheim, 1973, s. 16-17).

2 Bergson hafızayı pasif bir depo niteliğinde görmek yerine, hatırlamanın aktif katııı içerdiğini, akışkan ve değişken özellikte olduğunu öne sürmüştür. Halbwachs, Bergson'un zaman ve hafıza sorunsallaştırmasını, Durkheim'in sosyolojik perspektifinden değerlendirerek kolektif hafıza 
konusuna sosyal bir perspektif getirmiş ve kolektif hafıza yaklaşımını geliştirmiştir (aktaran Olick, 2008, s. 153). Yazara göre hatırlama büyük ölçüde diğer insanların hatırlatmasına bağlıdır. Bir toplumsal grup içerisinde gerçekleşerek hafızaya kaydedilen olaylar hatırlanırken de o toplumsal grubun bakış açısıyla zihinde canlanır. Bu durum kolektif hafıza kavramıyla açıklanabilir (Halbwachs, 1980, s. 33). Dolayısıyla hafızanın oluşumunda diğer kişilerle doğrudan ya da dolaylı ilişkilerin etkisi büyüktür. Ayrıca içinde bulunulan toplumsal grup hafızanın şekillenmesinde ve yeniden inşasında da etkilidir. Bu bağlamda bireysel düşünceler, bu toplumsal çerçeve içerisinde konumlanır ve kolektif hafızaya katılır. Bunun yanı sıra bireyler ait oldukları toplumsal grubun perspektifini de hafızalarına dâhil ederler. Kolektif hafıza da ait olduğu toplumsal sınıfın ya da grupların geleneklerinde kendini gösterir (Halbwachs, 1992, s. 38, 40). Buna göre hafıza sadece bireyin otobiyografik anılarına dayanmamakta; aynı zamanda pek çok kişinin ortaklaşa yaşadığı olaylar, deneyimler de hafızanın önemli bir kısmını oluşturmaktadır. Dolayısıyla hafıza bireysel bir fenomenmiş gibi görünse de aslında büyük ölçüde toplumsal olarak inşa edilmektedir.

Bu noktada bireyin hafızasının toplumsal çerçeve içerisinde şekillendiğinin, kolektif hafızanın da belli bir toplum ya da toplumsal grup içerisinde oluştuğunun, bu grubun sembollerinden, değerlerinden etkilendiğinin ve bu doğrultuda seçici olduğunun altını çizmek gerekmektedir. Yine de hatırlayan bireydir. Dolayısıyla hatırlama edimi bireyin özelliklerinden, duygusal ve psikolojik dünyasından, bakış açısından da etkilenmektedir. Bu bağlamda kolektif hafızanın işleyişini anlamada bireysel özellikler ile toplumsal etkiler bir arada düşünülmelidir.

Bir toplumda ya da toplumsal bir grup içerisinde ortak deneyimlere dayalı olarak oluşan kolektif hafızanın inşa süreci, internette kullanıcının içerik üretimine katılabilmesi sonucunda önemli bir değişim geçirmiş̧tir. Bu çalışmada kolektif hafızanın yukarıdaki özellikleri göz önünde bulundurularak yeni medyanın özellikleriyle birlikte nasıl bir dönüşümden geçtiğinin anlaşılması hedeflenmiştir. Bu bağlamda öncelikle kolektif hafıza ve medya ilişkisine odaklanılmış; sonrasında yeni medyanın bu süreçte nasıl bir değişim getirdiği anlaşılmaya çalışılmıştır. Son bölümde ise Türkiye'de ana muhalefet partisi lideri Kemal Kılıçdaroğlu'nun hukuk alanındaki sorunlara dikkat çekmek üzere gerçekleştirdiği "Adalet Yürüyüşü" örneği seçilerek, Ekşi Sözlük kullanıılarının kolektif hafıza inşası içerik analizi yöntemi kullanılarak incelenmiştir. Bu örneklem üzerinden, kolektif hafızanın yeni medyada kullanıc üretimi içerikler üzerinden nasıl inşa edildiği ve ne tür özelliklere sahip olduğu ortaya konmaya çalışılmıştır.

\section{Kolektif Hafıza ve Medya İlişkisi Üzerine}

Hafıza bayramlar, anıtlar, törenler, sözlükler, müzeler, halk sanatları, gelenekler, aile albümleri gibi hafıza mekânlarında somutlaşır, bu mekânlar aracılığıyla geleceğe aktarıır. Hafıza mekânları anıtlar, ulusal arşivler gibi somut 
olabileceği gibi; soy, ırk, din gibi düşünsel olarak oluşturulmuş soyut mekânlar niteliğinde de olabilir. Buna göre hafızanın oluştuğu ve taşındığı her alan hafıza mekânı olarak adlandırıır ve hafızaya ait önemli simgeleri yansıtır (Nora, 2006, s. 9-14). Bu bağlamda medya da hafıza mekânları olarak değerlendirilebilir. Bunun ötesinde iletişim araçları kolektif hafızanın sadece taşındığı, kaydedildiği ya da iletildiği mekânlar değil, aynı zamanda hafızanın kurgulandığı ve yeniden inşa edildiği ortamlardır.

Kolektif hafıza ve medya arasındaki ilişkiyi anlamak açısından toplumsal hatırlamanın iki biçimini oluşturan iletişimsel ve kültürel hafıza ayrımı önemlidir. Kişilerin birbirleriyle paylaştı̆̆ı anılara dayanan iletişimsel hafıza yakın geçmişle ilgili anılara gönderme yapar ve taşıyıcıları ile sınılıdır. Geçmişin belli noktalarına yönelen kültürel hafızada ise anılar sembolik hatırlama figürlerine bağlanarak saklanır. Metinlerin dışında, danslar, oyunlar, gelenekler, resim, maske, takı gibi kültürel öğeleri içeren kültürel hafıza tarih boyunca şamanlar, ozanlar, yazarlar, öğretmenler, filozoflar gibi kendine bilgiyi taşıma yetkisi tanınmış özel taşıyıcılar ile aktarılmıştır (Assmann, 2001, s. 51, 54-57, 62). Kolektif hafızanın bir formu olarak onu paylaşan insanlara kolektif ya da kültürel bir kimlik de sunan kültürel hafıza, iletişimsel hafızanın aksine bir bedene ya da zihne bağı değildir. Ancak bir hafıza görevi görebilmesi için toplumsal olarak saklanan, dolaşıma giren ve yeniden somutlaştırılan yapılara gereksinim duyar. Bu nedenle hafızanın oluşumunda toplumsal çerçevenin yanı sıra kültürel çerçeve de oldukça etkilidir. Dolayısıyla kültürel öğeler hatırlatma nesneleri olarak hafıza konusunun içine dâhil edilmedir (Assmann, 2011, s. 16-18). Bir topluluğun paylaştığı deneyimler üzerinden kurulan kolektif hafıza kültürel metin ya da unsurlar dolayımıyla geleceğe aktarılır. Medya da kültürel üretimin önemli bir bölümünü ortaya koyduğundan bu konuda belirgin bir işleve sahiptir.

Medya iletişimsel hafıza ile bireyden bireye aktarılan biyografik hafızaların saklanabilmesi için bir ortam sunabilmekte ve medyanın kodladığı bu hafızalar da toplumun uzun dönemli hafızası olan kültürel hafızayı oluşturmaktadır (Donk, 2009 , s. 4). Kurgulanmış geçmişin farklı iletişim kanallarından yaygınlaştırılması ile kültürel hafıza oluşmaktadır. Kültürel hafızada hafıza canlıdır ve inşası devam etmektedir. Bu süreçte iletişim araçları farklı metinlerden topladığı bilgilerle bir metinlerarası hafıza şeklini alabilir, sosyal ya da otobiyografik hafızanın bilgisini de doğrudan kullanabilir. Dolayısıyla geçmişin bilgisi dolayımlı bir şekilde aktarılmış ve kültürel hafıza kitle iletişimi ile şekillendirilmiş olmaktadır. Bu süreçte inşa edilmiş olsa da geçmiş, kitle iletişimi üzerinden taşındığında yaşam şansı bulabilmektedir (Başaran Ince, 2010, s. 15-16).

Medya olayları topluma aktararak kültürel hafızayı inşa etmektedir. Kolektif hafıza ise büyük ölçüde bu kültürel hafıza üzerinden inşa edilmektedir. Bu bağlamda Başaran İnce (2010, s. 15), hafızanın katmanlı yapısına dikkat çekerek kolektif hafızanın en altta yer aldığını; tarihsel ve kültürel hafıza ile deneyimler aracılığıyla şekillendiğini vurgular. 
Hafıza ve hatırlama sadece bireyin beyni aracılığıyla gerçekleşmemekte, not almak, fotoğraf çekmek, mesaj yazmak gibi edimler de hatırlama yetisini arttırmaktadır. Bu yöntemler beynin dışında anılar için bir depolama alanı oluşturur. Hatırlamaya yardımcı bu öğeler ve hafızanın saklandığı diğer ortamlar ise protez hafızalar ${ }^{3}$ olarak görülmektedir (Olick, 2014, s.194-195). Medya da ister geleneksel ister yeni medya teknolojileri olsun insanların protez hafızaları olarak işler. Garde-Hansen (2011, s. 7) günümüzde geçmişi yakalamanın, saklamanın gelişmiş bir düzeye geldiğini ve televizyon, film, mobil telefonlar, internet, sosyal medya gibi araçların hatırlamaya yardımcı olduğunun altını çizer.

Medya 20. yüzyıldan itibaren kamusal ya da özel tarihi bilginin kayıt altına alınma, arşivleme, inşa edilme ve yayılması konusunda ana kaynak haline gelmiştir. Bu açıdan medya geçmişin bilgisine erişmede en etkili araç olarak görülmekte, tarihi bilgileri canlandırmada da bilgi kaynağı konumuna gelmektedir. Ancak bu bilgilerin güvenilirliği ve gerçekliği sorgulanabilir niteliktedir. Geçmişin televizyon ya da sinemaya uyarlanmış görünümleri ile internetten yapılan araştırmalar, insanların tarihe dair fikirlerinin oluşumunda etkili olmaktadır. Böylece geçmiş medya söylemleri, formları, teknolojileri ve pratikleri üzerinden öğrenilmektedir (Garde-Hansen, 2011, s. 1-6). Jose van Dijck bu durumu dolayımlanmış hafıza (mediated memory) ifadesiyle açıklar. Medya hafızayı geliştirir, bozar, genişletir, kişisel hafızaları şekillendirir, bazı durumlarda hafızanın yerine geçer ve sonuç olarak hafıza dolayımlı bir şekilde oluşur. Dolayımlanmış hafızalar insanların bir geçmiş, gelecek ve şimdi anlamı yaratmak ve yeniden yaratmak üzere medya teknolojileri ile ürettikleri, sahiplendikleri eylem ve nesnelerden oluşur (van Dijck, 2007, s. 16, 21).

Geçmişin bilgisi, geçmişi unutturmamak için inşa edilmiş bir bilgidir. Bu genellikle bilinçli bir şekilde yapılır ve geçmiş şimdide yeniden inşa edilmiş olur. Bu süreçte medya belirleyici bir rol oynar. Otoriter ve totaliter rejimlerde ise medyanın bu geçmişi inşa etme rolü gerçekliğin tek yönlü bir yorumunu oluşturmayı içerir. Böylece iktidarın belirlediği bir geçmiş anlayışı medya tarafından inşa edilerek sunulur. Burada hegemonik bir temsil söz konusudur (Başaran İnce, 2010, s. 14, 24). İktidarın geçmişi yeniden inşa ederek aktarmasının nedeni Marcuse'ün geçmişin hatırlanması üzerine yaptığı yorum üzerinden de anlaşılabilir:

Geçmişin anımsanması, tehlikeli olabilecek bazı şeylerin iç yüzünün anlaşıImasına yol açabilir. Kurulu düzen toplum ise belleğin yıkıcı içeriğinden endişe duymaktadır. Anımsama, verilmiş gerçeklerden bir kopuş biçimi; kısa sürelerle de olsa, verilmiş gerçeklerin her an duyulan gücünü kesen bir "dolayımlaşma" biçimidir (Marcuse, 1968, s. 142).

3 Protez hafıza kavramı Alison Landsberg tarafından sinemanın, izleyiciler üzerinde aslında deneyimlemedikleri bir hafızanın oluşmasını sağladığını açıklamak üzere ortaya atılmıştır. Yeni medya ile birlikte bu olgu daha da belirginleşmiştir (Garde-Hansen, 2011, s. 62-63). (Ayrıca bkz. Landsberg, A (2004). Prosthetic Memory: The Transformation of American Remembrance in the Age of Mass Culture. New York: Columbia University.) 
Marcuse hafızanın kaybının, modern dünyanın gerçekliğin farklı boyutlarını yitirerek tek boyutlu hale gelmesini sağladığını öne sürer. Bu açıdan unutma ve unutturma totaliter yapıları konu alan distopyalarda da sıklıkla hegemonya oluşturma, kimlik inşası gibi amaçlarla kullanılan imgelerdir. Bunun nedeni hafızası olmayan toplumun sorgulama, eleştirme, bir kimliğe sahip olma gibi eylemleri yerine getiremeyeceğidir (Özhan Koçak \& Koçak, 2012, s.8-9). Geleneksel medya gündemdeki olayları topluma aktararak kolektif hafızanın oluşumuna dâhil olmakta, ancak sosyal gerçekliği sermaye ve iktidar ilişkileri çerçevesinde ilettiğinden kolektif hafızanın da belli bir bakış açısına göre inşasına yol açmaktadır.

Hafıza ve medya ilişkisi üzerine geliştirilen modellerin çoğu, geleneksel medyanın özellikleri üzerine kuruludur. Dolayısıyla kitle iletişimini temel alan bu yaklaşımlar hızla gelişen ve dijital içerik erişiminin, dolaşımının ve aktarımının yoğun olduğu ve böylelikle bireylerin, toplulukların ve toplumların hatırlama ve unutma pratiklerinin şekillendiği dönemi açıklamada yetersiz kalmaktadır. Yeni medyayla birlikte kamusal ve özel hafızanın iç içe geçtiği melez bir hafıza formu ortaya çıkmıştır. Sosyal ağ hafızası olarak nitelenebilecek bu hafıza formu bir yandan değiştirilmeye, kaybolmaya müsait olsa da sosyal ağlar üzerinden paylaşıldığından tamamen silinmeye karşı da dirençlidir. Dijital hafıza, bireylerin dijital medyayı hatırlamak üzere kullanması ve içerik üretimiyle aktif bir şekilde hafızanın oluşumuna katılmasına dayanır. Bu açıdan hafızanın oluşumu da daha esnek ve katııımı temsil sistemlerinin kapsamına girmiştir. Dolayısıyla yakınsama kültürünü temel alan teoriler hafızayı daha iyi açıklayabilmektedir (Garde-Hansen, Hoskins, \& Reading, 2009, s.3, 6-8).

Bu noktada bireyin içerik üretimine olanak veren yeni medyanın kolektif hafızaya etkisi üzerine düşünmek ve "İnternet üzerinden güncelin ya da geçmişin bilgisinin paylaşılması ve saklanmasının kitle iletişimi üzerinden kurulmuş hafızaya bir alternatif oluşturabilir mi?" sorusunu sormak gerekmektedir.

\section{Yeni Medyanın Kolektif Hafızaya Etkisi}

Fuchs (2008) interneti nesnelleşmiş insan bilgisini depolayan bilgisayar ağlarını içeren, merkezsizleşmiş bir teknolojik yapıya dayanan, küresel çapta tekno-sosyal bir sistem olarak görmektedir. İnsanlar bu küresel bilgi deposunu yeni enformasyon içeriği üreterek, iletişim kurarak, sistemde var olan enformasyonu tüketerek sürekli olarak yeniden yaratmaktadır. Bu kapsamda ağ hem teknolojik bir ara yüzdür hem de iletişim kuran insanları içermektedir (Fuchs, 2008, s. 122123). İçerik üretimine yardımcı araçların kolaylaşmasıyla birlikte, ağ üzerinden iletişim kuran insanların pratikleri katılımcı bir halk (folk) kültürünün canlanmasını sağlamıştır (Jenkins, 2001, s. 93). Bu bağlamda kullanıcı üretimi içeriğe dayalı sosyal medya örnekleri artmış; kullanıcılar medya içeriğinin hem üreticisi hem tüketicisi konumuna gelmiştir (van Dijck, 2009, s. 41-42).

Yeni medya alanındaki bu değişimle birlikte tüm iletişim formları karma, etkileşimli ve dijital bir hipermetinde eklemlenmiştir. Bu hipermetin insan etkileşimi 
sonucu ortaya çıkan tüm kültürel ifadelerin biraraya getirildiği, karıştııılığı, yeniden düzenlendiği bir yapıya sahiptir. Bu yapı sayesinde yeni medyadaki iletişim akışlarının kamuyu etkileyen mesajların çoğunun otonom üretimi ve çeşitliliği mümkün kılma potansiyeli bulunmaktadır. Ancak bu potansiyelin yanı sıra yeni medya kültürü üzerinde, medya kurum ve organizasyonlarının piyasa güdümlü işletme stratejilerinin de önemli etkisi bulunduğunu unutmamak gerekmektedir (Castells, 2009, s. 55, 71, 135).

Fuchs web 2.0 ve web 3.0 ile birlikte yaygın hale gelen sosyal yazılımların internette iletişim, topluluk oluşturma ve işbirliğinin baskın hale gelmesini sağladığını belirtir (2010, s. 784). Özellikle Wikipedia gibi kâra değil, bilgi paylaşımına dayalı olan platformlar kullanıcıların fiziksel olarak biraraya gelmeden dijital bilgi üretebilmelerine imkân sağlamaktadır. Bu anlamdaki bilgi üretimi bireylerin teker teker bilgilerini birleştirmelerinin ötesinde bir kolektif zekâyı ortaya koymaktadır (Fuchs, 2008, s. 131-135). Bununla birlikte özellikle kâra dayalı olan kullanıc üretimi siteler ticari ilişkilerden bağımsız düşünülemez. Dolayısıyla yeni medyada ne üretildiği ya da içeriğin nasıl gösterildiği gibi konularda kullanıcılar tam bir kontrole sahip değildir (van Dijck, 2009, s. 51-54). Ancak internetteki pek çok site kullanıcı üretimi içeriğe dayalıdır. Bu içerikler kolektif hafızanın inşası noktasında da önemli bir paya sahiptir.

Yeni teknolojilerle birlikte metin, görüntü ve seslerin ağ üzerinden, seçilmiş bir zaman diliminde, erişime açık ve farklı noktalarla etkileşim içerisinde iletilebilmesi iletişimin yapısını değiştirmektedir. Kültür iletişimle aktarıldığından kültürel alan da temelden dönüşmektedir (Castells, 2005, s. 440-442). Dijitalleşme, sosyal ağlar ile etkileşimin artması, kullanıcının içerik üretimine katkı sağlayabilmesi gibi eğilimler sadece yeni iletişim formlarının doğmasını sağlamamış, aynı zamanda kültürel alanı da önemli ölçüde etkileyerek yeni kültürel formların doğmasını sağlamıştır (Manovich, 2001, s. 6, 9).

Kültür ve kültürel ürünler kolektif hafızanın oluştuğu ve taşındığı ortamları oluşturduğuna göre yeni medyanın kültür üzerindeki etkisi kolektif hafıza açısından da geçerlidir. Bu bağlamda yeni medya ile ilgili yaşanan gelişmeler sonucunda hafızanın oluştuğu alanlar da dönüşüm geçirmiş, yeni hafıza pratikleri ortaya çıkmıştır. Böylece kolektif hafızanın oluşumu daha demokratikleşmiş, küreselleşmiş ve yeni ulus ötesi ortaklıklar ortaya çıkmıştır. İnternet siteleri, bloglar, sosyal medya platformları hafızanın kaydedildiği, anıların, anmaların gerçekleştiği ortamlar sunarak Nora'nın geleneksel hafıza mekânlarına dâhil olmuştur (Özhan Koçak, 2017, s. 5-6). Böylece insanların sosyal medya üzerinden paylaştığı bilgiler, düşünceler, karşılıklı konuşmalar, içerikler hafıza halini almıştır. Hafızanın oluşumu, kaydedilmesi ve arşivlenmesinin dijital bir şekilde gerçekleşmesi medya ve hafıza ilişkisinde önemli bir değişim ortaya koymuş; yeni bir hafıza formu oluşturmuştur. Bu açıdan dijital hafıza geleneksel medya ve yeni medya, üretim ve tüketim, kurumsal medya ve kullanıcı üretimi içerik arasında ortaya çıkan yeni ilişkilere dayalı olarak açıklanabilir (Garde-Hansen, Hoskins, \& Reading, 2009, s. 1, 13-14, 16). 
Yeni medyanın hafızanın doğası ile ilgili olarak sebep olduğu en önemli etkilerden biri bireysel ve kolektif hafıza arasında bir köprü kurulmasını sağlamasıdır. Internetle birlikte insanlar arasındaki bağlantısallık (connectivity) düzeyi artmıştır. Geçmişle, kamusal ya da özel alanla ilgili her türlü olay ya da bilgi; yeniden üretim ve dolaşımın hızlı ve düşük maliyetli olmasıyla kamusal olarak temsil edilebilir hale gelmiştir. Bireysel olarak üretilen hafızaya erişim önceden çok kısıtlıyken, yeni medyanın etkisiyle sosyal ağ hafızası olarak görülebilen yeni bir yarı kamusal, yarı özel bir hafıza oluşmaya başlamıştır. Bu hafızanın özellikleri ise akışkan, yersiz yurtsuz, dağılmış ve yüksek düzeyde geri alınabilir, anlık, erişimi kolay ve tesadüfi olmasıdır. Dijitalleşme hafızanın saklanması, arşivlenmesi, kurtarılması gibi konularda sınırsız olanaklar sunmuştur. Ancak bunlara karşın içerikler daha kolay değiştirilebilir niteliktedir (Hoskins, 2009b, s. 28- 30, 41).

Bireysel hafızaların internet üzerinden yayılması ve kamusal bir nitelik kazanması konusunda mobil telefonların sağladığı bilginin paylaşımı konusundaki anındalık ve hız da hafızanın yeni medyada geçirdiği dönüşüm konusunda önemli bir etkendir. Reading'e (2009, s. 81) göre mobil telefonlar memobile4 olarak adlandıııabilecek yeni bir dijital hafıza formunun oluşmasını sağlamıştır. Mobil telefonlar olayların anlık olarak kaydedilerek paylaşımasını, hızlı ve kolay bir şekilde mobilizasyonunu sağlar. Yazara göre telefonlar hafızaya bireysel ve giyilebilir bir gündelik yaşam arşivi niteliği kazanmıştır. Olaylar, hareket halindeyken kayıt altına alınabilir, belli bir zaman ve mekâna bağlı olmadan kurgulanabilir, küresel ağlarda paylaşılarak dolaşıma girip kaydedilebilir. Kamuoyunu ilgilendiren olayların bireyler tarafından anlık olarak kayıt altına alınarak paylaşıması kültürel hafıza kapsamındaki kamusal-bireysel, ulusal-uluslararası, somut-sanal gibi ayrımları da ortadan kaldırmaktadır (Reading, 2009, s. 88-90, 92).

Hoskins (2009a) de yeni medyanın hafıza alanında yeni bir form oluşturduğunu savunur. Sosyal medya üzerinden kullanıcıların kendi yaşamlarına dair bilgileri, çeşitli konularla ilgili yorumları kamusal ya da yarı kamusal bir şekilde paylaşması, hafızanın insanların bu sosyoteknik pratikleri içerisinde inşa edilmesine yol açmıştır. Hoskins'e göre dijital ağ hafızası olarak görülebilecek bu hafıza formunda iletişim süreci içerisinde dinamik bir şekilde bilgi girilebilir, değiştirilebilir ya da silinebilir. Böylece dijital ağ hafızası bir tür yaşayan arşivsel hafıza şeklini alır (Hoskins, 2009a, s. 92).

Kolektif hafıza ile ilgili olan geleneksel görüş bireysel ve kolektif hafızaların birbirinden ayrı şeyler olduğu ve medya gibi teknolojik mekanizmalar ya da arşiv gibi toplumsal kurumlar aracılığıyla biraraya geldiği üzerinedir. Ancak hafızanın kuruluşunda dijital ağların etkisi giderek artmaktadır. Böylece hafızanın kurucu özneleri hem teknolojik hem insani bir özelik kazanmıştır (van Dijck, 2010, s. 402). Yaradılışları gereği dijital hafıza nesnelerinin birçoğu ağlaşmış nesnelerdir

4 Reading'in memobile kavramın türetirken İngilizce'deki me (kendim), mobile (mobil) ve memory (hafıza) kelimelerini biraraya getirmiştir. Kavram ayrıca internet üzerinden virüs gibi yayılan kültürel birimler olan meme'lere de gönderme içermektedir (Reading, 2009, s. 82). 
ve ağ üzerinde farklı bireylerin etkileşimleri sonucu müşterek bir şekilde oluşturulmuşlardır (van Dijck, 2007, s. 48). Hoskins (2009a, s. 94) de dijital medyanın ağa dayalı yapısına vurgu yaparak hatırlama ediminin de ağlaşmış bir şekilde ve anında gerçekleştiğini belirtir.

Hoskins artık gündelik yaşamın kopyalama, kurgulama, iletme, paylaşma, bağlantılandırma (linking), beğenme gibi eylemleri içeren hiperbağlantısallığa (hyperconnectivity) dayalı bir şekilde yaşandığını ve bu durumun verilerin tamamen ortadan kaldırılması, unutulması, silinmesi gibi olasılıkları zorlaştırdığını belirtir. Dijitalleşmeden önce geçmişin bilgisi fiziksel etkilere açık, bozulabilen, sararıp solabilen nitelikteydi. Bu nedenle Hoskins, geçmişin medyasını çürüyen bir alan, 20. yüzyılı ise çürüme çağı (decay time) olarak görür. Dijitalleşme öncesinde medyanın bozulabilir nitelikte olmasının günümüzde bir hafıza patlaması yaşanmasına yol açtığını düşünür. Dijitalleşme ve hiperbağlantısallık ile birlikte insanların geçmişinde silikleşmeye başlayan kişilerin, olayların Google, Facebook, Youtube gibi ortamlar aracılığıyla tekil bir bağlantılı şimdiye (a single connected present) geri döndürüldüğ̈nü düşünür (Hoskins, 2013, s. 387).

Hoskins (2011) bağlantısal hafıza kavramını bağlantı kurmanın, hafızanın inşasıyla kesiştiğini vurgulamak üzere kullanmaktadır. Bağlantıııık hafızayı radikal bir biçimde dönüştürmektedir. Hafıza bağlantılıık ile birlikte bireysel ya da kolektif hatırlamanın bir ürünü olmaktan çıkarak insanların, dijital ortamların arasındaki bağlantıların akışı içerisinde inşa olmaya başlamıştır (Hoskins, 2011, s. 272). Bu sayede dijital alan yaşayan bir arşiv özelliği kazanır. Yeni medyadaki yayılma, virallik gibi özellikler sayesinde hafıza da dijital alanda yayılmıştır. Ancak paradoksal bir şekilde hafızanın dijital alandaki varlığı bozulma, bağlantısızlık (disconnection), silinme gibi etkilere de maruz kalabilmektedir (Hoskins, 2013, s. 388). Dijital verilerin kaybolabilir, silinebilir, değiştirilebilir, gelip geçici, akışkan olması gibi özelliklere sahip olmasından dolayı bağlantısal hafızanın güvenilirliği de düşüktür (Hand, 2014, s. 208).

Dijital teknolojilerden önce geçmişin bilgisini saklamanın yüksek bir maliyeti vardı ve bundan dolayı hafızanın kaydedilmesi de belli bir kesimin elindeydi. Ancak günümüzde veri saklama, bulma, arama gibi işlemler hem ucuz hem de küresel olarak erişilebilir bir nitelik kazanmıştır. Böylece hafızanın oluşumuna katıım da kolaylaşmıştır (Garde-Hansen, Hoskins, \& Reading, 2009, s. 1).

Yeni medyanın önemli etkilerinden biri de olayların küresel olarak yayılabilmesine olanak sağlayarak kültürel hafızanın oluşumundaki en önemli unsurlardan biri olan tanıklık edilmesini yaygınlaştırmasıdır. Bunun yanı sıra yeni medya iletişimsel ve kültürel hafızanın da yakınsamasını sağlamış ve hafızanın oluşumu üzerinde resmi kurumların etkisini zayıflatmıştır (Başaran İnce, 2014, s. 21). 
Yeni medya unutmayı zorlaştırmıştır. Mayer-Schönberger'e (2011) göre dijital teknolojiler ve küresel ağlara kadar olan dönemde unutma bir kaide, hatırlama edimi ise istisna olarak görülmekteydi. Ancak günümüzde ağlar sayesinde bu durum tersine dönmüștür. Insanların sosyal ağlarda paylaşıp da sonradan unutulmasını istediği bilgiler olsa bile, bu verileri internet "hatırlamaktadır". insanlar tarih boyunca hatırlamak ve bilgilerini aktarmak üzere hafızalarını güçlendirmek için kitaplar, günlükler, videolar gibi dışsal hafıza yerine geçecek araçlar geliştirmiştir. Zaman içinde insanların hatırlama biçimleri ve kapasiteleri farklılaşmıştır. Dijitalleşmenin bilginin paylaşılması, işlenmesi, saklanması, geri getirilmesi gibi konuları kolaylaştırması hatırlama ve unutma arasındaki dengeyi değiştirmiştir. Geçmişte hatırlama daha maliyetli ve zor bir edimken günümüzde unutma ve unutturma daha maliyetli ve zor bir hal almıştır (Mayer-Schönberger, 2011, s. 1-2, 48-49, 62, 92).

Sayısallaşma ile saklama maliyetinin ucuzlaması, küresel erişilebilirlik, kolay geri kazanım gibi özellikler yeni medyanın hafıza açısından olumlu katkıları olarak görülse de dijital verilerin kaypak, güvenilmez ve soyut olması, sayısal uçurum ${ }^{5}$ ve bilgisizlik gibi sorunlar da olumsuz etki oluşturmaktadır (Başaran Ince, 2014, s. 11). Bir diğer önemli sorun da yeni medyada hafızaya dair bilgilerin geleceğe aktarılmasının zorluğudur. Insanların yaşamlarına dair bıraktıkları izler dijital iletişimleri içerisinde kalmaktadır. Gelecekte bu verilerin saklanabileceği, korunabileceği de net değildir. Bu nedenle e-postalarda, sosyal medya sitelerinde, internette oluşan özel ya da yarı kamusal iletişimin oluşturduğu verilere güncel olarak erişilebilse de bu verilerin kültürel hafızanın bir parçası olarak geleceğe aktarılabileceği şüpheli görünmektedir. Ayrıca bu dijital verilere erişimin kolay olması da verileri manipülasyona açık hale getirir (Hoskins, 2009a, s. 102).

Yeni medyada kolektif hafızanın oluşumuna ilişkin sorunlardan biri de politik sansürdür. Internet insanlara fikirlerini açıklayabilme anlamında bir alan açsa da devletler çeşitli yasal düzenlemelerle siteleri erişime engelleme, kapatma gibi yaptırımlar uygulayabilmektedir. Bazı örneklerde de Facebook, Twitterve Youtube gibi platformlar devletlerin talebi doğrultusunda içerikleri kaldırabilmektedir. Türkiye' de de bu tür site kapatma ve engelleme örnekleri6 görülmektedir. Özellikle Gezi Hareketi sonrasında internet bu anlamda iktidarın daha çok dikkatini çekmeye başlamıştır. Bu dönemde insanlar, sosyal medyada paylaştıklarından dolayı işten

5 Sayısal uçurum (digital divide), dijital medya ve internete erişim konusunda insanlar arasında sosyo-ekonomik düzeye bağlı olarak ortaya çıkan eşitsizliklere gönderme yapan bir kavramdır. Küresel ya da yerel düzeyde yoksulların enformasyona erişim konusunda daha dezavantajlı olduklarını ifade eder (Moyo, 2009, s. 123). Dolayısıyla internete erişimi kısıtlı olan kesimlerin yeni medyadaki kolektif hafızanın oluşumuna katıımı da sınırıdır.

62015 yılında Youtube, Twitter ve Facebook'un da aralarında bulunduğu pek çok sosyal medya ve haber sitelerine erişim yasağı getirilmiştir (Alternatif Bilişim Derneği, 2016). 2008'de iki yıl boyunca engellenen Youtube hakkında 2014'e kadar 30'un üzerinde kapatılması yönünde mahkeme kararı alınmıştır (Akgül \& Kırıdoğ, 2015, s. 7). Benzer şekilde belli maddelerinden dolayı çevrimiçi bir ansiklopedi niteliğinde olan tüm Wikipedia sitesi Nisan 2007'den itibaren erişime kapatılmıştır (Türkiye'de Wikipedia'ya Erişim Engeli, 2017). 
atılma, soruşturma geçirme, gözaltına alınma gibi sorunlarla karşı karşıya kalmıştır (Innceoğlu \& Çoban, 2015, s. 33-34). Bunun yanı sıra insanların içerik yüklemesini engelleme amaçlı olarak internetin yavaşlatılması da bir sansür stratejisi olarak kullanılabilmektedir (Alternatif Bilişim Derneği, 2016, s. 3). Türkiye'de internet içeriğini denetlemeyi düzenleyen 5651 sayılı kanun, mahkeme kararı olmadan internet sitelerine erişimin engellenebilmesi ve içeriğin yasa dışılığının nasıl belirleneceğinin açık olmaması nedeniyle eleştirilmektedir. Ayrıca dava konusu olan içeriğe erişimin kısıtlanması yerine tüm siteye erişimin engellenmesi de en çok eleştirilen konulardan biridir (Henkoğlu \& Yılmaz, 2013, s. 226). Çeşitli suç içerikli sitelerin hukuken denetlenmesi bir zorunluluk olsa da politik nedenlerle internetin kısıtlanması ifade özgürlügünü ve dolayısıyla da yeni medyada kolektif hafızanın oluşumunu kısıtlamaktadır. Buna karşın erişim yasağı getirilen sitelerin yeni alan adları alarak, kapatılan sosyal medya hesapları yerine yenilerini açarak ya da kullanıcılarını teknik olarak bilgilendirip erişim engelini aşmaya yönlendirerek bu sorunların üstesinden gelmeye çalıştıkları da görülmektedir (Alternatif Bilişim Derneği, 2016, s. 3).

Dijital teknolojiler hızlı bir şekilde gelişip değişmektedir. Yeni medyada veri saklama formatlarının çok hızlı değişmesi de saklanan verilerin korunması konusunda sorunlara yol açmaktadır. Donk (2009) bu sorunu somutlaştırarak, son 20 yılda kaydedilen dokümanların günümüz bilgisayarlarınca deşifre edilemediğinin altını çizer. Bu tür sorunların dijital medyadan kaynaklanan kolektif bir amnezi konusunda endişelere yol açtığını vurgular. Yazılım ve donanımlardaki bu hızlı değişim kayıt formatlarının da uyumsuz hale gelmesine yol açmaktadır. Dijital verilerin saklandığı ortamlar 20 yıldan fazla veriyi saklama konusunda yetersizdir ve veriler kolayca silinebilir. Ayrıca internet siteleri de bilgileri arşivlenmeden kaldırılabilmekte, sayfaları kapatabilmektedir. Bu sorunlar dijital amnezi tehlikesini doğurur. Dijital amnezi kültürel hafızanın kaybolmasına yol açabilmekte bunun sonucunda da kolektif kimliklerin de kaybolma riski ortaya çıkmaktadır (Donk, 2009 , s. 2-3, 7-8). Dolayısıyla yeni medya veri saklanmasını ucuzlatsa da verinin uzun süre korunması konusunda teknik sorunlar bulunmaktadır (Özhan Koçak \& Koçak, 2012, s. 7).

Her teknolojide olduğu gibi bazı dezavantajlar, beklenmedik olumsuz etkiler oluşabilmektedir. Dijital amnezi konusundaki endişelere dikkat çeken Donk (2009) dijital verilerin kaybolabilme olasılığını da bu olumsuz etkilerden biri olarak görür ve bu noktada sorunların çözümü üzerine düşünmek gerektiğini savunur. Bu açıdan dijital amnezi sorununu teknolojik determinizme dayalı olarak görür ve ampirik temelinin olmadığını vurgular. Ayrıca hafızanın tarihini saklama ortamlarıyla sınırlamamak gerekmektedir. Hafıza insanların hatırlamasıyla doğrudan bağlantııdır. Dolayısıyla hafızanın korunması konusuna teknolojik değil toplumsal bir perspektiften bakmak daha doğrudur (Donk, 2009, s. 13-14).

Yeni medyanın kolektif hafızanın oluşumu açısından olumlu tarafı bireysel hafızaların ve tanıklıkların kolayca dijital ortama aktarılabilmesidir. Bu açıdan 
kolektif hafızaya dair bilgiler geleneksel medya kanalları devre dışı bırakılarak ağlar boyunca yayılabilir (Garde-Hansen, 2011, s. 46). Özellikle web 2.0'nin içerik üretimine olanak sağlamasıyla birlikte bireyler de kendi deneyimlerini, bakış açılarını içeren hafızalarını kayıt altına alıp paylaşarak kolektif hafızanın inşa sürecine dâhil olabilmektedir. Böylece kolektif hafızanın inşası toplumsal kurumların, iktidarın ya da medyanın belirleyiciliğinden kurtulmaya başladığı düşünülebilir. Ancak bu noktada devletlerin internet içeriğine müdahaleleri de göz ardı edilmemelidir.

Internetin bireyselleşmeyi desteklemesi, hatırlama ediminin de çoğulcu bir nitelik kazanmasını sağlamıştır. Özellikle ana akım ve resmi hafızadan dışlanmış olan azınlıktakilerin bakış açıları ya da hafızaları internet üzerinden yayılabilmektedir. Bu nedenle internet bireysel hafızaların kolektif, kolektif hafızanın da bireysel hale gelebildiği bir ortam sunar (Donk, 2009, s. 13).

Web 2.'nin kullanıcılara tanıdığı içerik üretimi konusundaki imkânlarla sosyal ağ platformlarının artışı yeni bağlantılar ve kolektifliklerin kurulmasını kolaylaştırmış ve yeni hafıza formları ve kültürleri doğmasını sağlamıştır (Hoskins, 2009b, s. 30). Çalışmada incelenen Ekşi Sözlük de kullanıcının içerik üretimi üzerinden inşa edilen kolektif hafızanın oluştuğu ortamlardan biridir. Bu örnekte içerik üreten kullanıcıların çeşitli olay ya da konularla ilgili bilgi, deneyim, tanıklık ve izlenimlerini internet ortamına aktararak kolektif hafızanın inşasına katılıkları görülmektedir. Bu noktada çeşitli görsellerin, metinlerin, alternatif bilgi kaynaklarının, hipermetinlerin belirgin olduğu kullanıcı üretimi bir kolektif hafıza inşa edilmektedir.

\section{Kullanıcı Üretimi Kolektif Hafıza: Adalet Yürüyüşü İncelemesi}

Ekşi Sözlük, kullanıcılarının çeşitli kavram, olay, kişi ve durumlar hakkında görüşlerini, tanımlamalarını, bilgilerini aktardığı, kolektif olarak üretilen çevrimiçi bir sözlük olma özelliğine sahip bir internet sitesidir. Sitede gündemdeki gelişmeler ile ilgili kullanıcılar başlıklar açabilmekte bu başlıklarda kendi görüş ve tanıklıklarını, konuyla ilgili farklı kaynak, haber ya da bilgileri paylaşabilmektedir. Kurulduğundan beri 18 yıldır kullanıcıların her konuda ve çoğunlukla da gündemle paralel bir şekilde bilgi, yorum, tanımlama, tanıklıklarını yazmalarıyla Ekşi Sözlük geçmişe dair bir konunun da hatırlanabilmesi için kayıt oluşturmakta, arşiv özelliği göstermektedir.

Sözlükte markalardan, kavramlara, şarkılardan, ünlü kişilere kadar pek çok konu başlığının olmasının yanı sıra gündemdeki olaylar, gelişmeler hakkında da çok sayıda başlık açılmaktadır. Bu açıdan alternatif bir gündem kullanıcılar tarafından sözlük içerisinde oluşturulur. Yazarlar pek çok başlı̆̆ı da başına tarih ekleyerek oluşturur. Bunun yanı sıra sözlükte "tarihte bugün" sekmesiyle, geçmiş yıllarda o günde hangi başlıklar açıldığı görülebilmekte, bu başlıklarda gezinilebilmektedir. Bu özellikleriyle Ekşi Sözlük yeni medyadaki hafıza mekânlarından birini oluşturmakta ve kolektif hafızanın da inşa edildiği bir ortam halini almaktadır. Bu sebeplerle 
çalışmada yeni medyada kolektif hafızanın inşa sürecini anlamak üzere kullanıcı üretimi içeriğe dayalı ortamlardan Ekşi Sözlük seçilmiş, bu kapsamda örnek olay olarak da yakın dönemdeki önemli tarihi ve siyasi gelişmelerden biri olan "Adalet Yürüyüşü" alınarak sözlükte bu konuda girilen entryler ${ }^{7}$ içerik analizi yöntemi ile incelenmiştir.

Adalet Yürüyüşü son yıllarda Türkiye' de hukuk alanında yaşanan sorunlar ve hukukun siyasallaşması konusundaki eleştiriler sonucunda ana muhalefet partisi olan CHP'nin başlattığı sivil bir harekettir. CHP milletvekili Enis Berberoğlu'nun tutuklanması sonucunda CHP "herkes için adalet" sloganı ile hukuk alanında sorun yaşayan herkes için Ankara'dan İstanbul'a 25 gün sürecek 432 km'lik bir yürüyüşle sivil bir protesto gerçekleştirmeye karar vermiştir8. Örnek olay olarak bu konunun seçilmesinde yürüyüşün belli bir süreci içermesi ve önemli tarihi gelişmelerden biri olması etkili olmuştur.

Ekşi Sözlük'te bu konuyla ilgili olarak pek çok başlık açılmış; kullanıcılar Adalet Yürüyüşü ile ilgili olarak bilgi ve yorumlarını paylaşmıştır. İçerik analizine en çok entry girilen "15 haziran 2017 chp Güvenpark yürüyüşü" ile "9 temmuz 2017 istanbul maltepe adalet mitingi" başlıkları dâhil edilmiştir. İlk başlık yürüyüşün başlangıcını ve yürüyüş sürecini; ikinci başlık ise yürüyüşün sonuçlanmasını ve sonunda gerçekleştirilen mitingi içermektedir. Birinci başlık için 107 sayfa; ikinci başlık için 110 sayfa entry girilmiştir. Her sayfada 10 entry bulunmaktadır. İçerik analizine her sayfadan 5. ve 10. entryler dâhil edilmiş; enrtyler özelliklerine göre aşağıdaki gibi kategorize edilmiştir. Toplamda ilk başlıktan 214; ikinci başlıktan 220 entry içerik, uzunluk, tarih, dış bağlantı içermesi açısından değerlendirilmiştir. Çalışmanın kapsamına ve amacına uygun olarak içerik analizinde kullanılmak üzere bu araştırmaya özgü bir kodlama cetveli oluşturulmuştur. Entryler bu kodlama cetveline göre kategorize edilmiştir.

7 Ekşi Sözlük jargonunda her başlık içerisindeki yazar yazıları entry (giriş) olarak adlandırımaktadır. Çalışmada da sözlük jargonu takip edilerek yazarların girişleri için entry ifadesi kullanıımıştır.

8 http://t24.com.tr/haber/kilicdaroglu-kac-kilometre-katedecek-adalet-yuruyusu-kac-gunsurecek,409256. (Erişim Tarihi: 01.09.2017). 
Tablo 1. İçerik Analizi İçin Oluşturulan Kodlama Cetveli

\begin{tabular}{|l|l|}
\hline Entrylerin Özellikleri & Entry'nin yazıldığı tarih \\
\hline Tarih & Entry'yi oluşturan kelime sayısı \\
\hline Uzunluk & Başlık içerisine entry yazan yazar sayısı \\
\hline Yazarlar & $\begin{array}{l}\text { Okuyucuları farklı başıklara ya da internet sitelerine yönlendi- } \\
\text { ren hiper bağlar içeren entryler }\end{array}$ \\
\hline Hiperbağ İçerme & $\begin{array}{l}\text { Diğer yazarlara tepki içeren ya da onların yorumlarına cevap } \\
\text { niteliğindeki entryler }\end{array}$ \\
\hline Tepki / Cevap İçerme & \multicolumn{2}{|l|}{} \\
\hline Entrylerin İçeriği & $\begin{array}{l}\text { Adalet Yürüyüşü'nü Ekşi Sözlük'te tanımlayan ve yürüyüş } \\
\text { hakkında bilgi veren entryler }\end{array}$ \\
\hline Tanımlayıcı & $\begin{array}{l}\text { Yazarların yürüyüş ya da mitinge katılarak kişisel tanıklıklarını, } \\
\text { gözlemlerini, deneyimlerini aktardıkları entryler }\end{array}$ \\
\hline Tanıklık İçeren & $\begin{array}{l}\text { Geçmişteki ya da tarihteki bir olaya, habere, kültürel metine } \\
\text { vb referans içeren ve böylece o olayı ya da tarihin anımsan- } \\
\text { masını sağlayan entryler }\end{array}$ \\
\hline Hatılatıcı & $\begin{array}{l}\text { Yazarların yorumlarını içeren entryler. Bu entryler yazarın } \\
\text { yürüyüş konusundaki tavrına göre olumlu, olumsuz ve nötr } \\
\text { yorumlar olarak da kategorize edilmiştir. }\end{array}$ \\
\hline Yorumlayıcı &
\end{tabular}

\section{İçerik Analizi ve Bulgular}

Içerik analizi kapsamında öncelikle Adalet Yürüyüşü ile ilgili olarak Ekşi Sözlük'te kullanıcı üretimi içeriğe dayalı oluşan kolektif hafızanın yapısal özelliklerini ortaya koymak üzere entryler girildikleri tarihe, uzunluğuna ve yazarına göre incelenmiştir. Ayrıca entryler, hiperbağlar içerip içermedikleri ve diğer kullanıcıların yorumlarına tepki ya da cevap niteliğinde olup olmadığına göre de değerlendirilmiştir. Analizin ikinci aşamasında ise entryler içerdikleri bilginin ya da verinin niteliğine göre analiz edilmiş, bu bağlamda içeriksel olarak tanımlayıcı olma, tanıklık içerme, hatırlatıcı olma ve yorumlayıcı olma şeklinde kategorize edilmiştir.

Yürüyüş belli bir süreci içerdiğinden bu süreç içerisinde hangi yoğunlukta giriş yapıldığını anlamak üzere tarihsel bir kategorizasyon yapılmıştır. Entryler tarihe göre kategorize edildiğinde her iki başlıkta da entrylerin belli bir günde yoğun olarak girildiği görülmektedir. Her iki başlıkta da olayın yaşandığı gün en çok entry girilmiştir. Bu konuda sözlüğün ana sayfasının her gün yeni başlık açılıkça güncellenmekte oluşu etkilidir. Entrylerin olayın gerçekleştiği günde yoğunlaşması ikinci başlıkta daha belirgindir. İlk başlık yürüyüşün tamamını kapsadığından 25 günlük süre boyunca az da olsa her gün içerik girilmiştir. 
Grafik 1. Enrtylerin Günlük Dağlımı (Başıık 1)

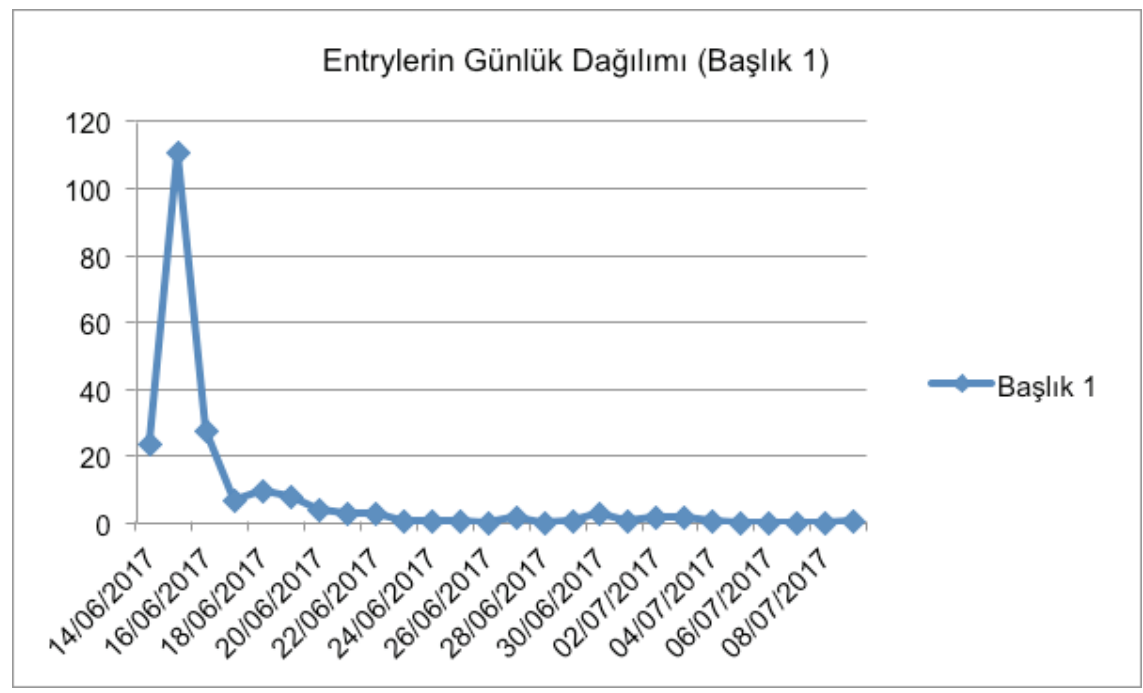

Grafik 2. Entrylerin Günlük Dağılımı (Başlık 2)

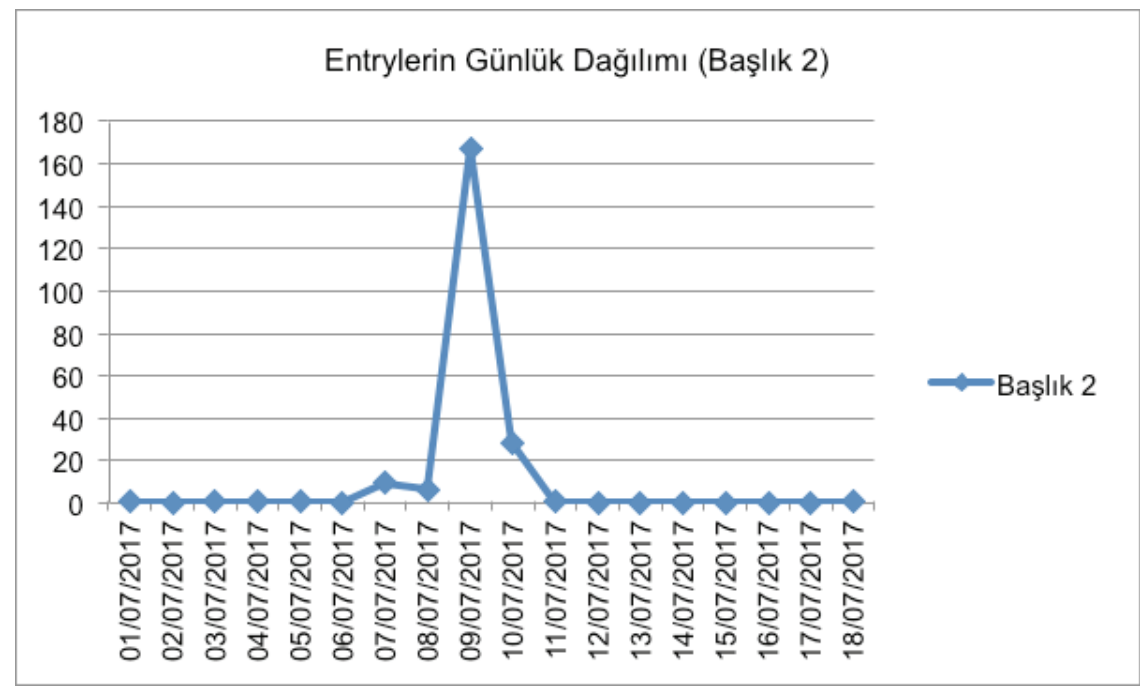

Entryler uzunluk açısından incelendiğinde buradaki bilgilerin kısa ve öz bir şekilde aktarıldığı görülmektedir. Detaylı ve uzun içerikler ise sayı olarak daha azdır. Entrylerin yarıya yakını 10-50 kelime arasındadır. Entrylerin \%17'si ise 10 kelimenin altındadır. Bunlar daha çok kısa yorumlar, farkıı başlıklara yönlendiren hiperbağlardan oluşmaktadır. 
Grafik 3. Entrylerin Uzunluğu

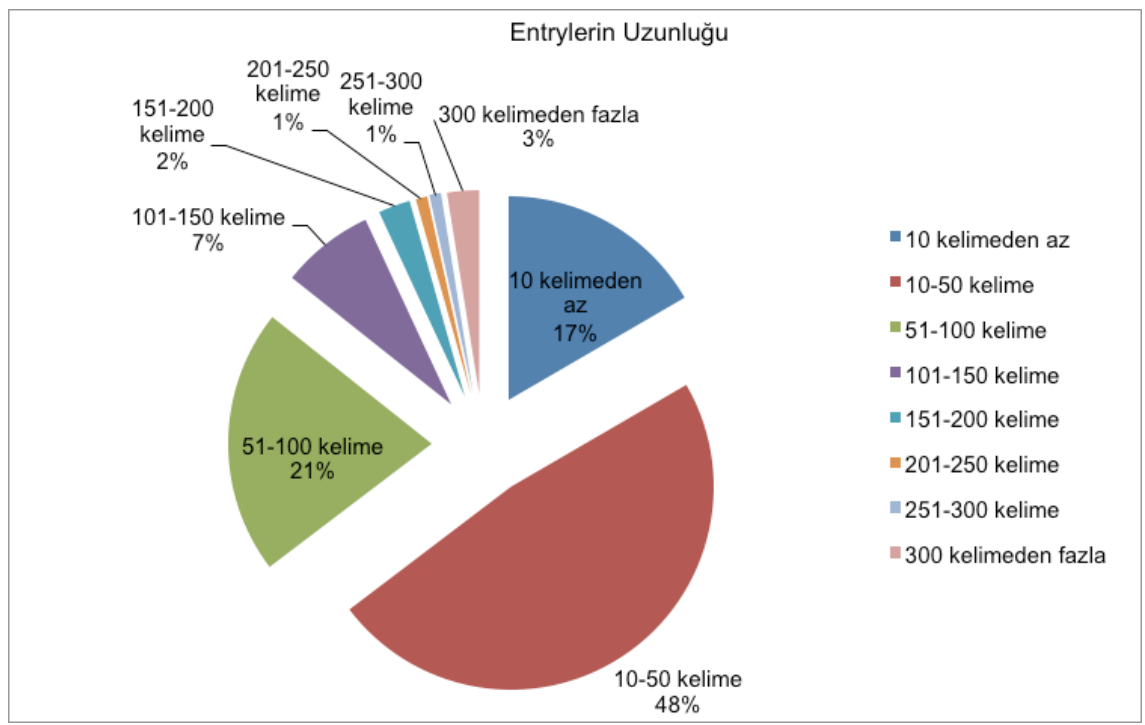

Olayların kısa ifadelerle açıklanması, yorumlanması yönünde bir eğilim olması internet kültürüyle bağlantılı olarak yorumlanabilir. Günümüzde hızlı, kısa, özet şeklinde hap bilginin tüketilmesi yönünde bir eğilim bulunmaktadır. Twitter'da 140 karakterle düşüncelerin ifade edilmesi yönünde bir sınırlama olması bunun örneği olarak görülebilir.

Çin'in Twitter'ı niteliğinde olan Weibo'daki hafıza inşası üzerine yapılan bir incelemeye göre günümüzde hafıza inşası daha kısa süreli, geçici, parçalanmış niteliktedir. Enformasyon akışlarının hızlanması, gündemdeki olayların medya platformlarında kısa ömürlü olması ve hızlıca unutulmasına yol açmaktadır. Weibo gibi ortamlarda da anlık güncellemeler, canlı bildirimler, olaylara şahit olan bireylerin paylaşımları enformasyonun akış hızını arttırmakta, geleneksel medya bu tür platformların anındalığını yakalayamamaktadır. Şimdi geçici bir nitelik kazanmakta, anında geçmişe dönüşmekte, kısa ömürlü akışkan ve parçalanmış hale gelmektedir. Bunun sonucunda oluşan kolektif hafıza da aynı şekilde parçalanmış niteliktedir (Le Han, 2016, s. 82-83).

Yeni medya ucuz ve kolay bir saklama alanı sunsa da deneyim ve olayların kaydedilmesi birbirinden kopuk veriler şeklinde, zamansalıı ve mekânsalııtan uzak niteliktedir. Bu açıdan yeni medyadaki veriler dijital kültürün oluşturduğu yığın içinde kaybolabilmektedir. Bu yönüyle yeni medya toplumsal hafıza ve kimliğin korunmasında yetersiz görülmektedir. Bu anlamda ortaya çıkan hafıza kaybı da gerçekliğin farklı yönlerinin kaybedilerek tek boyutlu bir toplumun oluşmasına katkı sağlar (Özhan Koçak \& Koçak, 2012, s. 3). Ağda bilgi yığını şeklinde 
arşivlenen bu bilgiler düzenlenmedikçe, korunup aktarılmadıkça kolektif hafızanın taşıyıcısı olmak yerine veri parçaları şeklinde kalır. Bu durum enformasyonun bilgiye dönüşmesini engeller. Ayrıca bu düzenlemeyi kimin yapacağı da sosyal hafızanın kontrolü sorununu beraberinde getirir (Özhan Koçak, 2017, s. 9).

Weibo örneğine geri dönülürse Le Han'a (2016) göre bu konuda karamsar ve iyimser olmak üzere iki yaklaşım bulunmaktadır. Karamsar yaklaşım, bir olay yaşanırken büyük oranda kamusal tartışma ve ilgi oluştuğunu, ancak bu parçalanmış ve izole bilgilerin kesin ve uzun süreli bir kolektif hafıza oluşumunu sağlayamadığını ifade eder. İyimser yaklaşım ise sosyal medya çağında, kolektif hatırlama açısından belli bir bilgi parçasının kamusal alanda sahip olduğu etkiyi önemli görür. Çünkü bu bilgi parçaları resmi kanalların dışında farklı perspektifler sunabilmektedir. Le Han (2016) de enformasyon güncellemelerinin hızlı olması ve olayların yoğunluğunun artmasının, Weibo üzerinden belli bir olayla ilgili uyumlu, mantıklı ve kapsayıcı bir anlatının oluşmasının çok mümkün olmadığını belirtir. Ancak yazar olayla ilgili parçalı bilgilerin sosyal medyada yayılması ve belli bir zaman dilimi içerisinde yoğun olarak yer kaplamasının olayların yeri, dâhil olan kişiler, tanıklar, kurbanlar, failler gibi anahtar kelime niteliğindeki parçalı bilgilerin kolektif hafızanın merkezini oluşturduğunu belirtir (Le Han, 2016, s. 83, 85). Ekşi Sözlük gibi ortamlarda da benzer bir durum bulunmaktadır. Buradaki bilgiler hızlı ve anlık olarak güncellenmektedir. İncelemede de görüldüğü gibi 25 günlük bir süreci kapsayan bir olayla ilgili olarak sadece ilk başladığı gün içerisinde yoğun olarak bilgi girilmiştir. Bu bilgilerin büyük bölümü de kısa ifadelerden oluşmaktadır. Bu nedenle bu olayla ilgili olarak kullanıııların ürettiği hafızanın kapsayıcı olmayan, anlık, parçalı ve kısa bilgilere dayandığı görülmektedir. Yine bu bilgilerin kamusal olarak paylaşıması farkı perspektifleri göstermesi açısından önemli görülebilir.

Başlıklar yazarların çeşitliliği açısından da incelenmiştir. Buna göre ilk başlıkta 195 farklı kullanıcı toplamda 214 entry girmiştir. 13 kullanıcı 2'şer, 3 kullanııı ise 3 'er giriş yapmıştır. İkinci başlıktaki değerlendirme de ilkini doğrular niteliktedir. Bu başııta da 208 farklı kullanıcı 220 entry girmiştir. Sadece 12 kullanıc 2'şer enrty girmiştir. İki başlık bir arada incelendiğinde 388 farklı kullanıcının 434 entryi girdiği görülmektedir. 33'ü 2'şer; 7'si 3'er entry girmiştir. Sadece 15 kullanıcı iki başlığa birden entry girmiştir. Bu rakamlar bize başlıklarda farklı seslerin kendini ifade etmesi anlamında yüksek düzeyde bir çeşitlilik olduğunu göstermektedir. Dolayısıyla belli bir konu ya da olay hakkında aynı kişiler yorum ya da içerik üretmemiş, kullanıııların kolektif hafızanın oluşumuna katkı sağlama anlamında önemli bir çeşitlilik gösterdiği görülmüştür. Belli bir görüş, bakış açısı hâkim olsa da söz söyleyenlerin sayısının yüksek olması önemli görülebilir.

Internetin önemli özelliklerinden biri de web sayfalarının hiperbağlarla farkı web sayfalarına bağlanabilmesidir. Entryler yapısal olarak bu açıdan da değerlendirilmiştir ve aşağıdaki sonuçlar ortaya çıkmıştır: 
Grafik 4. Hiperbağların Dağılımı (Başlık 1)

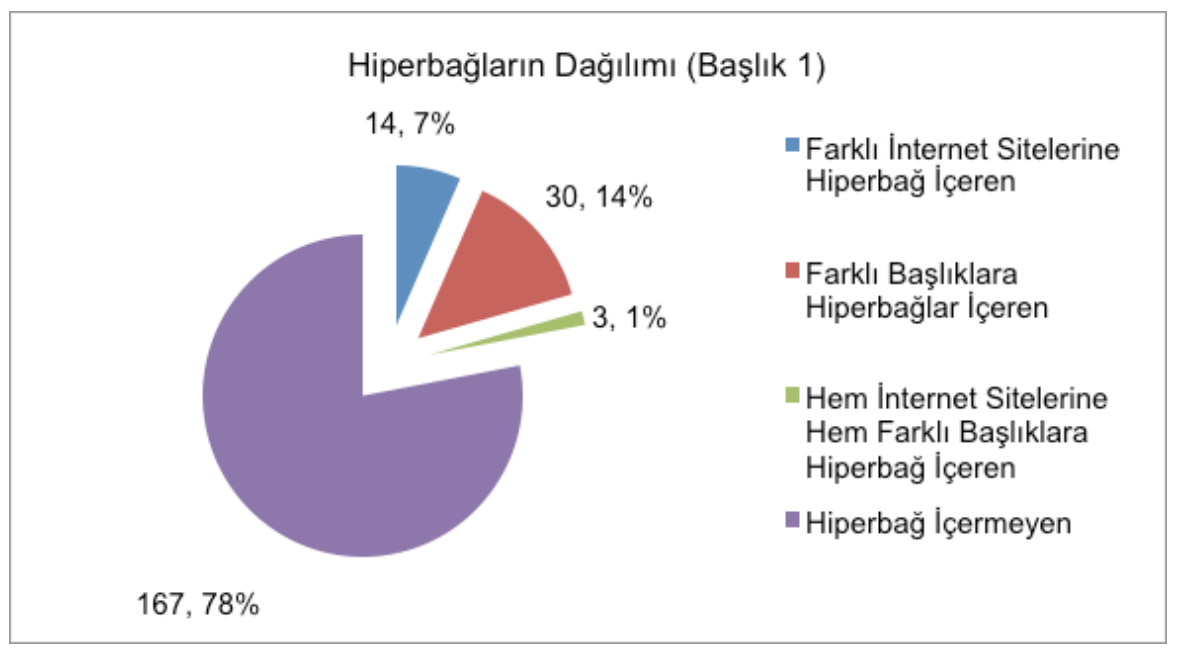

Grafik 5. Hiperağların Dağıımı (Başlık 2)

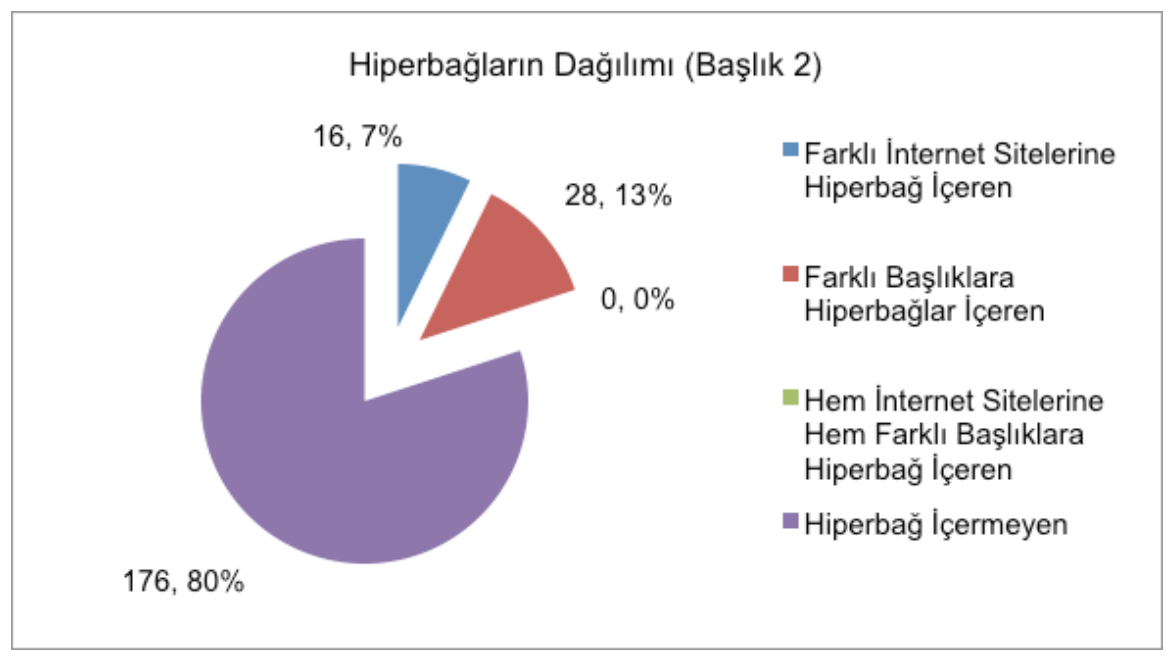

Buna göre ilk başıkta \%22, ikinci başlıkta ise \%20 düzeyinde hiperbağ içeren enrty bulunmaktadır. Okuyucuları farklı başlıklara ya da web sayfalarına yönlendirme eğilimi iki başlıkta da benzer çıkmıştır. Farklı sayfalara hiperbağlar Youtube, fotoğraflar veya farklı haber sitelerine bağlantılar içermekte ve olaylarla ilgili destekleyici bilgiler verme amacı taşımaktadır. Entrylerin bir bölümü ise konuyla ilgili farklı başlıklara bağlantılar vererek okuyucuyu yönlendirme amacı taşımaktadır. Bunlar farklı bir olaya ait gibi, ironi oluşturmak amaçlı deyiş ve ifadeleri içeren başlıklar da olabilmektedir. 
Araştırma kapsamındaki gözlemler sırasında bazı entrylerin diğer kullanıcılara ve içerik üreticilere tepki ya da cevap niteliğinde olduğu dikkat çekmiştir. Entryler bu açıdan kategorize edildiğinde ilk başııta \% 17, ikinci başııkta ise \%3 entry farklı kullanıcılara cevap içeren, tepkisel içeriklerden oluşmaktadır. Bu tür entrylerin varlığı Ekşi Sözlük içerisinde tartışmaların yaşandığını, küçük kamusal alanlar oluşabildiğini ve farklı bakış açılarının oluştuğunu göstermesi açısından önemli görülebilir. Ancak bu tür entrylerin oranı ikinci başlıkta oldukça düşüktür. İlk başlıkta aşağıda görüleceği gibi yorumların da daha fazla olması cevap niteliğindeki entrylerin sayısının da ikinci başlığa göre daha yüksek çıkmasına yol açmıştır.

Grafik 6. Tepki / Cevap İçeren Entrylerin Dağıımı (Başlık 1)

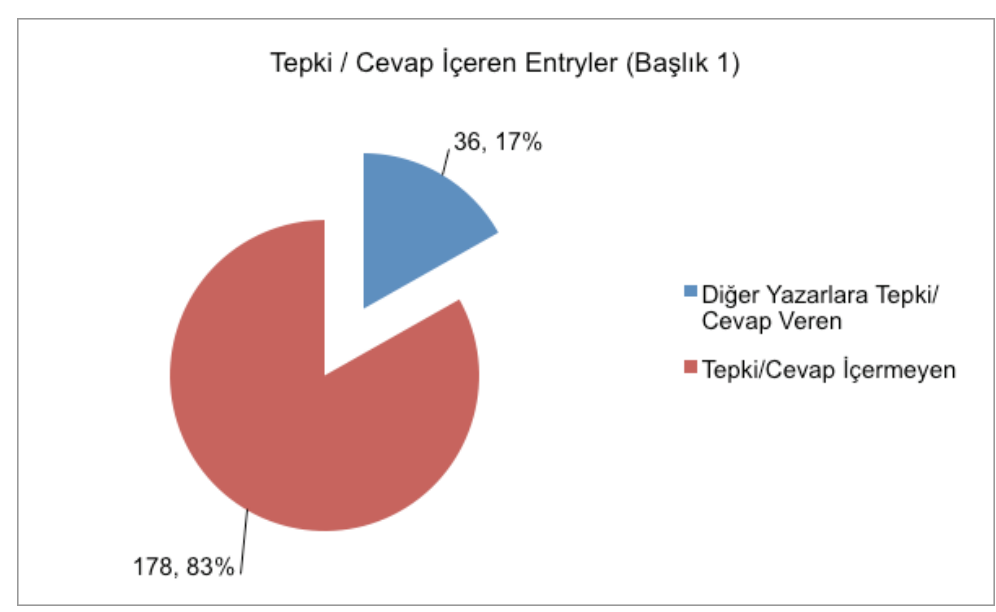

Grafik 7. Tepki / Cevap İçeren Entrylerin Dağılımı (Başlık 2)

Tepki / Cevap İçeren Entryler (Başılı 2)

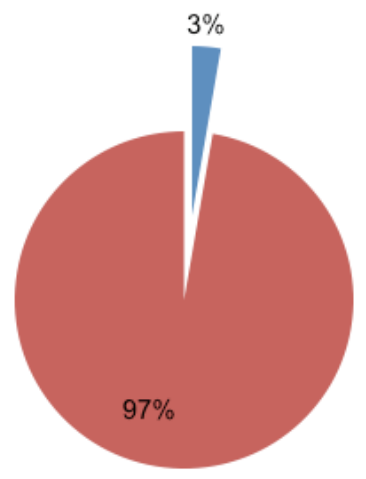

- Diğer Yazarlara Tepki/

Cevap Veren

- Tepki/Cevap İçermeyen 
Analizin ikinci aşamasında entryler içeriklerine göre kategorize edilerek değerlendirilmiştir. Araştırma kapsamında entrylerin tanımlayıcı, tanıklık içeren, hatırlatıcı ve yorumlayıcı veriler içerdiği görüldüğünden dolayı bu dört ana başlıkta kategorizasyon yapılmıştır. Entryler bu içerik özelliklerinin birini ya da birkaçını bir arada içerebilmektedir. Her ne kadar içerik analizinde kategorilerin birbiri içine geçmesi tercih edilmese de bu çalışmada analiz edilen entryler farklı nitelikteki cümlelerden oluşabilmekte, tanımlayıcı, tanıklık, yorumlayıcı ya da hatırlatıcı ifadeleri bir arada içerebilmektedir. Bu sorunu aşmak üzere aşağıda kategorilerin birbiri içine geçmediği detaylı bir dağılım oluşturulmuştur.

Grafik 8. İçeriğe Göre Detaylı Dağılım (Başık 1)

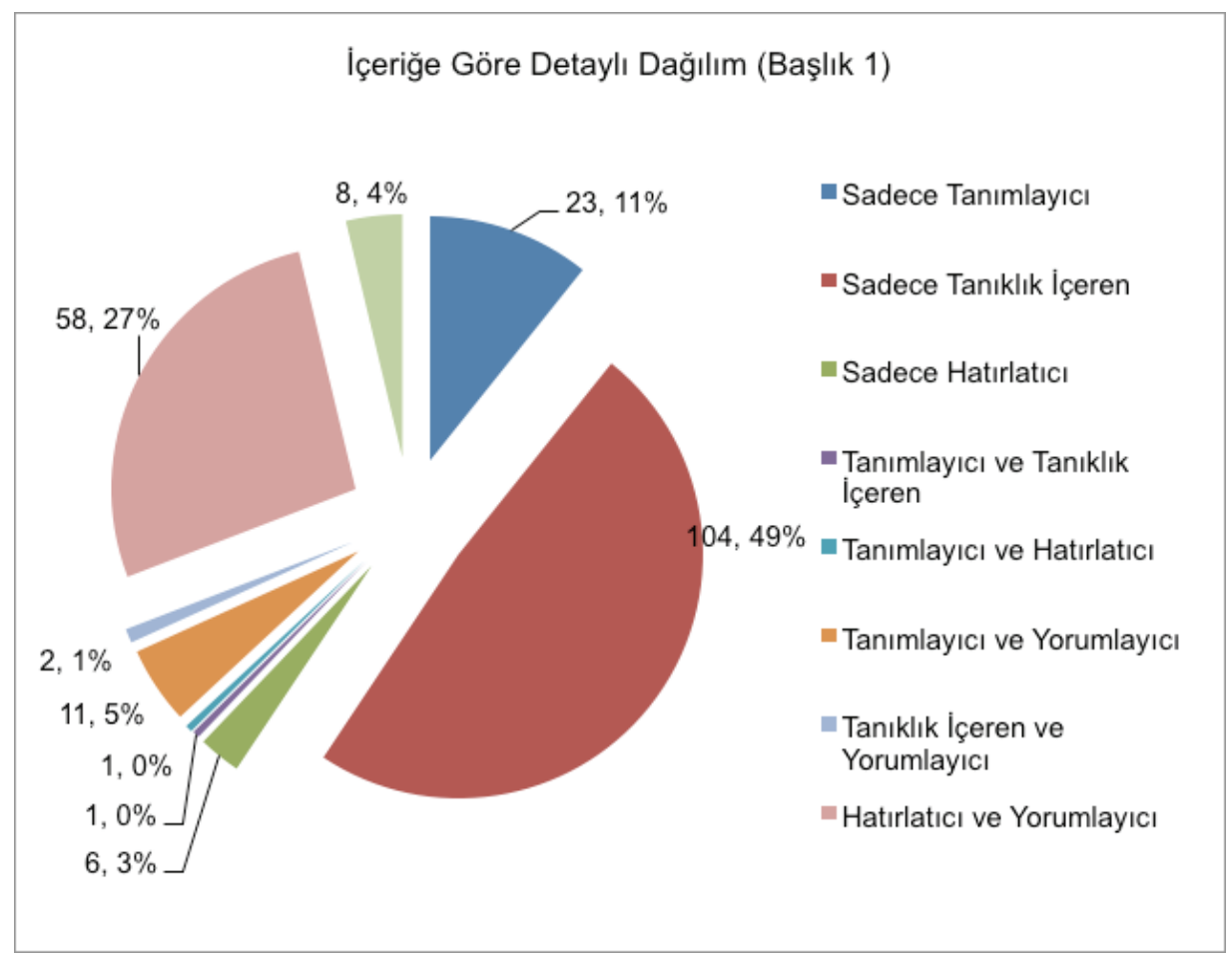


Grafik 9. İçeriğe Göre Detaylı Dağılım (Başlık 2)

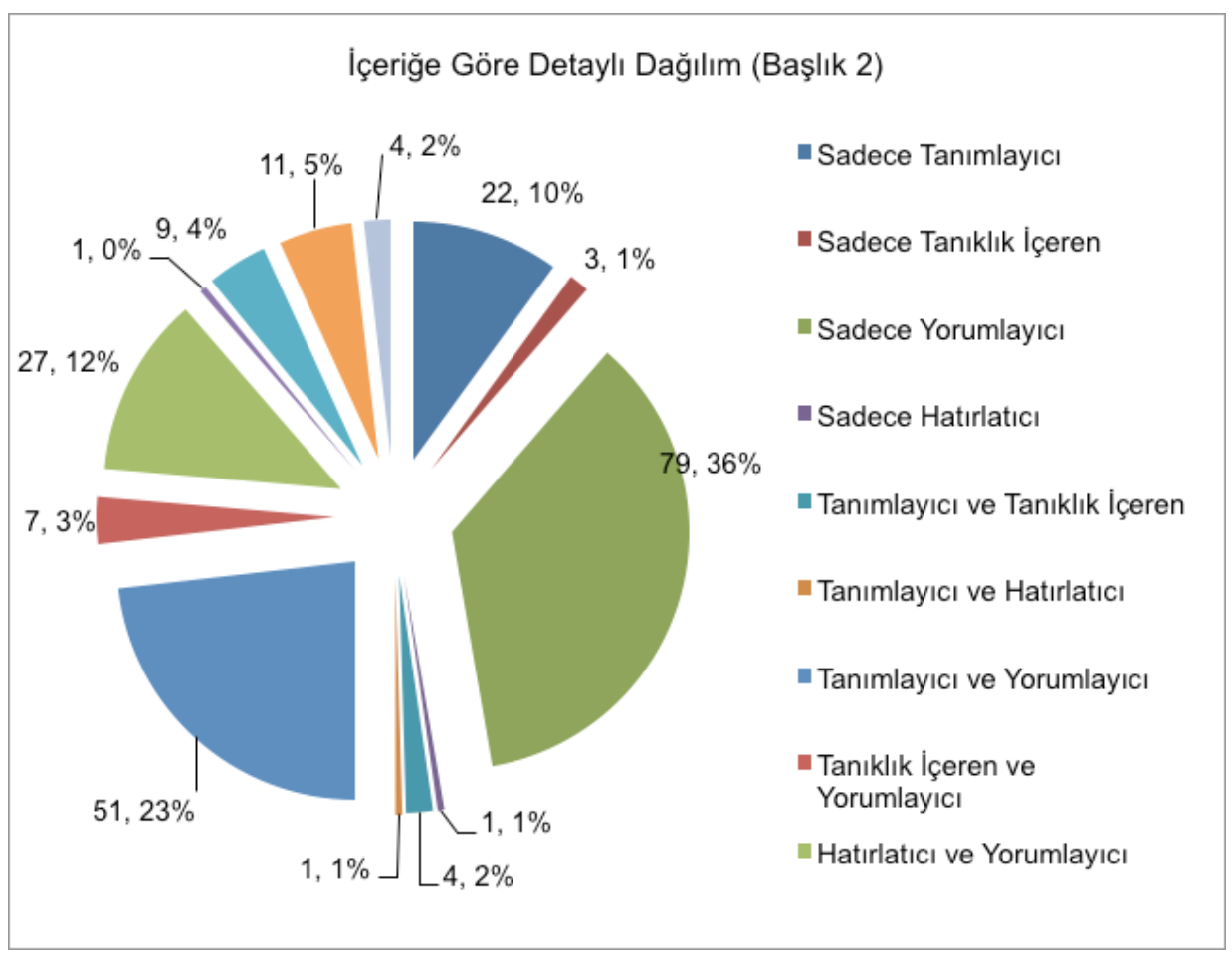

Yukarıda sadece yorum içerikli entrylerin iki başlıkta da en yoğun olduğu görülmektedir. İlk başlıkta yorumlayıcı ve hatırlatıcı ifadeler, ikinci başlıkta ise yorumlayıcı ve tanımlayıcı ifadeler ikici sırada gelmektedir.

İçeriklere göre yapılan dağılımda entrylerin tanımlayıcı ifadeler ve tanıklık içermesi olayla ilgili bilgi vermesi açısından önemlidir. Bunun nedeni tanım ve tanıklık içeren entrylerin ana akım medyanın ya da iktidarın sunduğu bilgiye alternatif bilgi kaynağı oluşturması ya da insanların deneyimlerini yansıtmasıdır. Hatılatıcı entryler geçmiş olay ya da haberlere göndermeler içerdiğinden kolektif hafızanın canlı tutulması açısından öneme sahiptir. Yorumlayıcı ifadeler ise belli bir ortamda oluşan kolektif hafıza içerisindeki farklı perspektifleri, görüşleri yansıtması açısından önemlidir. Bu nedenle bu dört ana kategori ayrı ayrı da değerlendirilebilir. Bu bağlamda içeriğe göre dağılım aşağıdaki gibidir: 
Grafik 10. İçeriğe Göre Dağııım

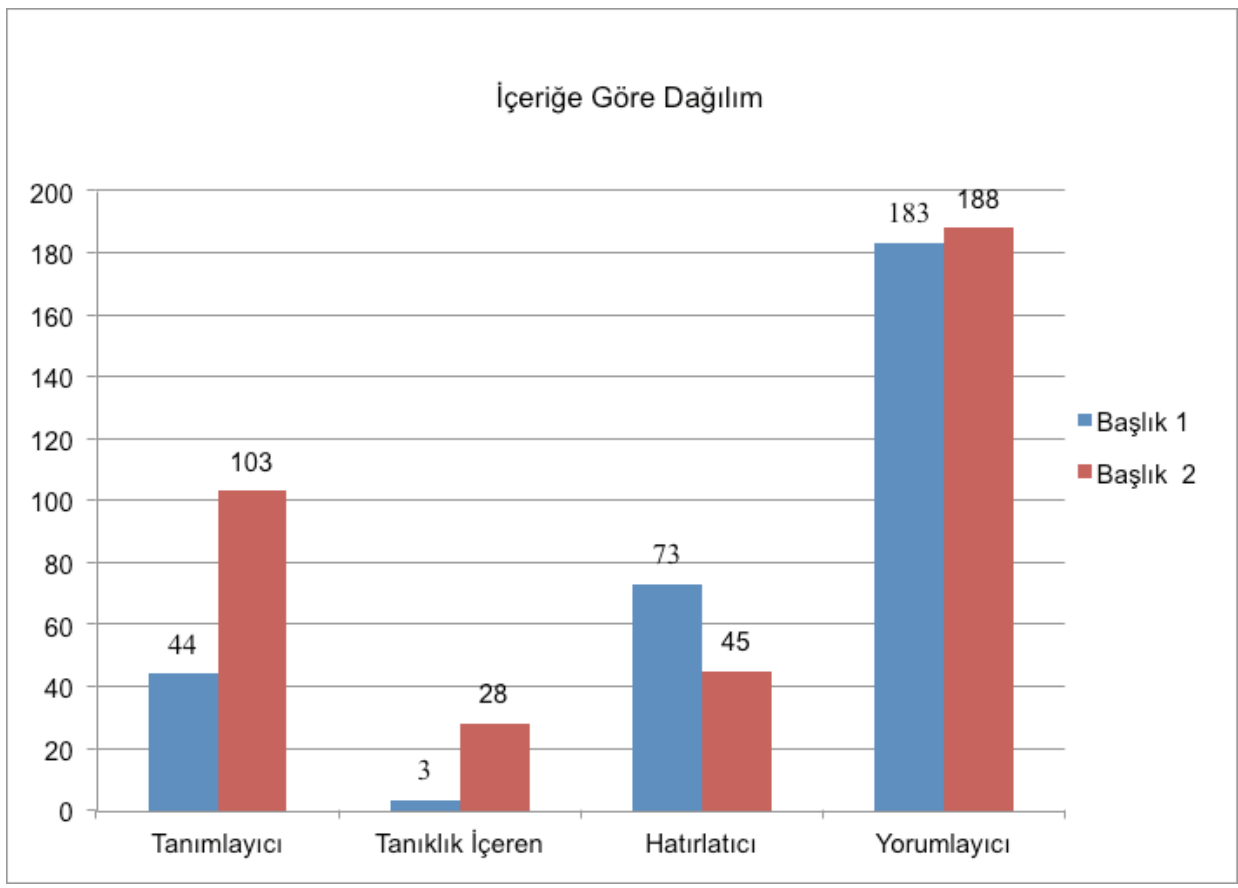

Entrylerin büyük çoğunluğunu mutlaka yorum içermektedir. İlk başlıkta 214 entryden 183'ü; ikinci başlıkta ise 220 entryden 188'i mutlaka yorum içermektedir. İlk başlıkta ikinci olarak hatırlatıcı ifadeler; üçüncü olarak tanımlayıcı ifadeler bulunmaktadır. Íkinci başlıkta ise tanımlayıcı ifadeler ikinci sırada; hatırlatıcı ifadeler üçüncü sırada gelmektedir. Bunun nedeni ilk başlıkta kullanıcıların CHP'nin yürüyüş kararına ilk tepki olarak geçmişteki olayları referans göstererek geç kalındığı yönünde bir yorumun ortaya çıkmasıdır. İkinci başlık ise olayın sonucundaki nüfusun yoğun olduğu İstanbul'da geçekleşen mitingle ilgili olduğundan tanıklıklar ve tanımlayıcı ifadeler daha yoğundur.

İçerikler incelendiğinde yeni medyada kolektif hafızanın inşası açısından yorumların ön plana çıktığı görülmektedir. Bu noktada yeni medyanın bireye kendini ifade etme anlamında olanak sunmasının bireylerin de kişisel fikir ve görüşlerini yoğun olarak yansıtmalarına yol açtığı söylenebilir. Bu noktada yeni medyada kolektif hafıza inşa edilirken öncelik yorum ve görüşlerin iletilmesi olmuştur.

Kullanıcıların dijital medyada hafıza oluşturma, kaydetme araçlarına daha demokratik bir şekilde erişebilmesi geleneksel medyanın izleyicilerinin artık 
hatırlamanın yeni yollarını oluşturmada dijital teknolojileri nasıl ve ne ölçüde yaratıcı olarak kullandıklarının incelenmesi gerektiğini göstermektedir. GardeHansen, Hoskins ve Reading (2009) bu noktada dijital hafıza konusundaki pratiklerin geleneksel teknolojilere dayalı hafıza pratiklerini temel aldığını ve bunların dijitale uyarlandığı sonucuna ulaştıklarının altını çizer. Bu süreçte tabanın oluşturduğu tarih bloglar, bireysel gazetecilik, akran ağları, çevrimiçi sayfalar gibi dijital pratiklerle dolayımlanmaktadır (Garde-Hansen, Hoskins, \& Reading, 2009). Bu çalışmada da yorumların kolektif hafıza içerisinde baskın bir yere sahip olması, internet kullanıcıarının da olayları aktarırken kendi bakış açılarıyla dolayımladıklarını göstermektedir. Ayrıca yorumlar politik eğilimleri de göstermektedir. Dolayısıyla kolektif hafıza, tarafsız olmak yerine belli bir görüş doğrultusunda inşa edilme eğilimi göstermektedir. Olayın tanımlanması ve bilgi verilmesi ikinci planda kalmıştır.

Tanımlayıcı ifadeler, konuyla ilgili bilgi vermesinden dolayı kolektif hafızanın oluşumunda önemli bir yere sahiptir. Örneklerde de ikinci başlıkta tanımlayıcı ifadelerin öne çıktığı görülmektedir. Bu noktada ilk başlıkta yürüyüşün başlangııını içeren olay daha plansız ve aniden gerçekleştiğinden konuyla ilgili yorumlar öne çıkmıştır. İkinci başlıkta ise 25 günlük bir yürüyüşün sonucunda gerçekleşmesi beklenen bir mitingi ifade etmektedir. Dolayısıyla bu olayda bir beklenti ve merak oluşmuş; kullanıcılar da olayı tanımlama, bilgi verme intiyacı daha yüksek çıkmıştır şeklinde yorumlanabilir.

Kolektif hafızanın sürdürülmesi ve canlı tutulması açısından geçmişin hatırlatılması gerekmektedir. Bu açıdan, çalışmada önemli olan ikinci nokta da içeriklerin geçmiş referanslarının yoğun oluşudur. IIlk başlıkta 72 entryde, ikici başlıkta ise 45 entryde hatırlatıcı ifadeler bulunmaktadır.

Tanıklıkların ifade edilmesinin ise daha düşük düzeyde kaldığı görülmüştür. Yine de ikinci başlıkta bu oran daha yüksektir. Mitingin yapılacağının günler öncesinde belli olması, en büyük ve kalabalık ilde gerçekleşmesi ve dolayısıyla kullanıcılar arasında katııımın da daha yüksek olması dolayısıyla tanıklık içeren ifadeler daha yoğundur.

Yorumlar incelendiğinde kullanıcılar arasında konuya bakış açısının yakın olduğu görülmüştür. Ancak Ekşi Sözlük kültürel bir topluluk olarak değerlendirilirse, benzer bakış açılarının olması normaldir. Zaten kolektif hafıza konusu da belli bir toplumsal grubun hafızasını ifade etmektedir.

Inceleme kapsamında yorumlar öne çıktığından yorumlayıcı entryler Adalet Yürüyüşü'ne bakış açısı temel alınarak da kategorize edilmiştir. Bu kapsamda yürüyüşün kendisi referans alınarak yorumlar olumlu, olumsuz ya da tarafsız olup olmamasına göre de değerlendirilmiştir. 
Grafik 11. Yorumların Dağıımı (Başlık 1)

\section{Yorumların Dağılımı (Başlık 1)}

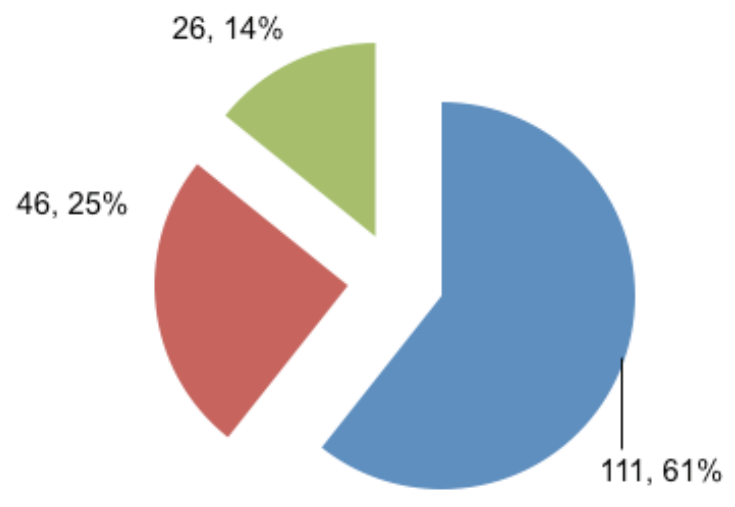

- Olumlu

- Olumsuz

- Tarafsız

Grafik 12. Yorumların Dağıımı (Başlık 2)

\section{Yorumların Dağılımı (Başlık 2)}

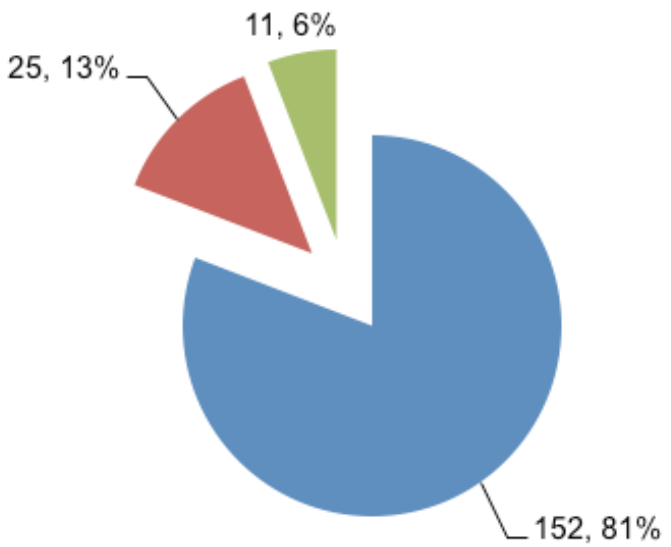

- Olumlu

- Olumsuz

- Tarafsız

İnceleme sırasında bazı olumlu yorumların CHP, Kemal Kılıçdaroğlu ya da medya konusunda eleştirel olduğu gözlemlenmiştir. Yürüyüşle ilgili olumsuz yorumlar ise iktidarı destekleyip desteklememesine göre de değerlendirilmiştir. 
Grafik 13. Olumsuz Yorumların Dağılımı (Başlık 1)

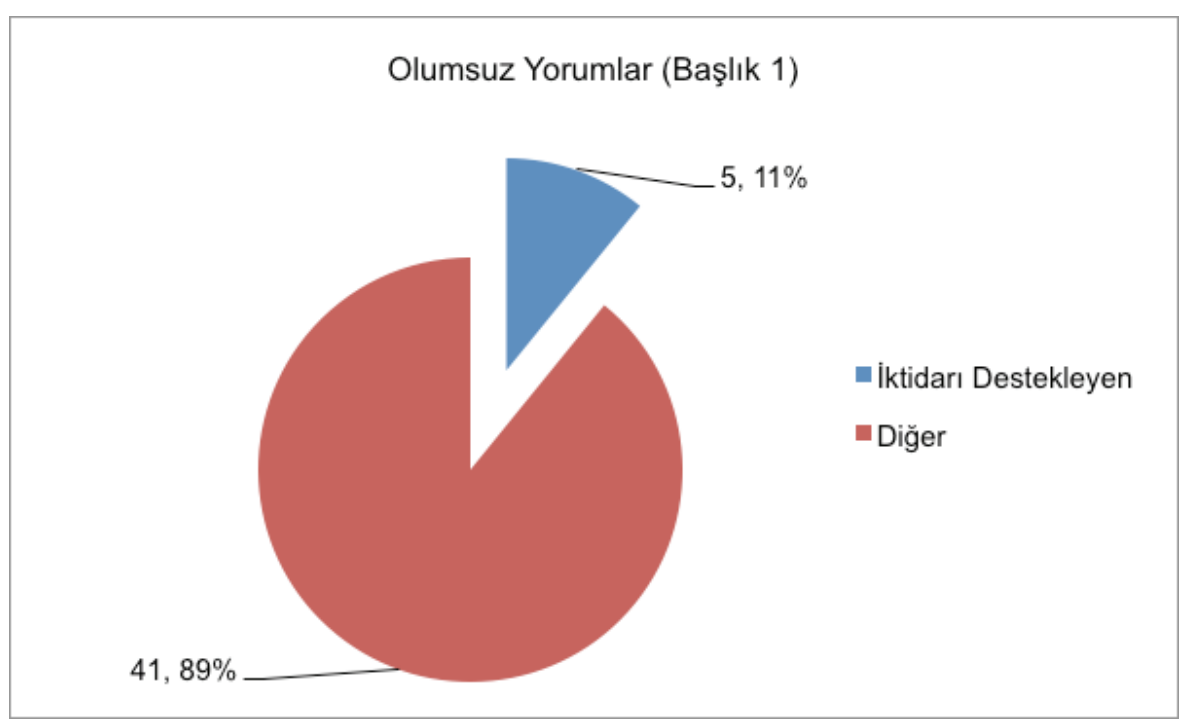

Grafik 14. Olumsuz Yorumların Dağıııı (Başlık 2)

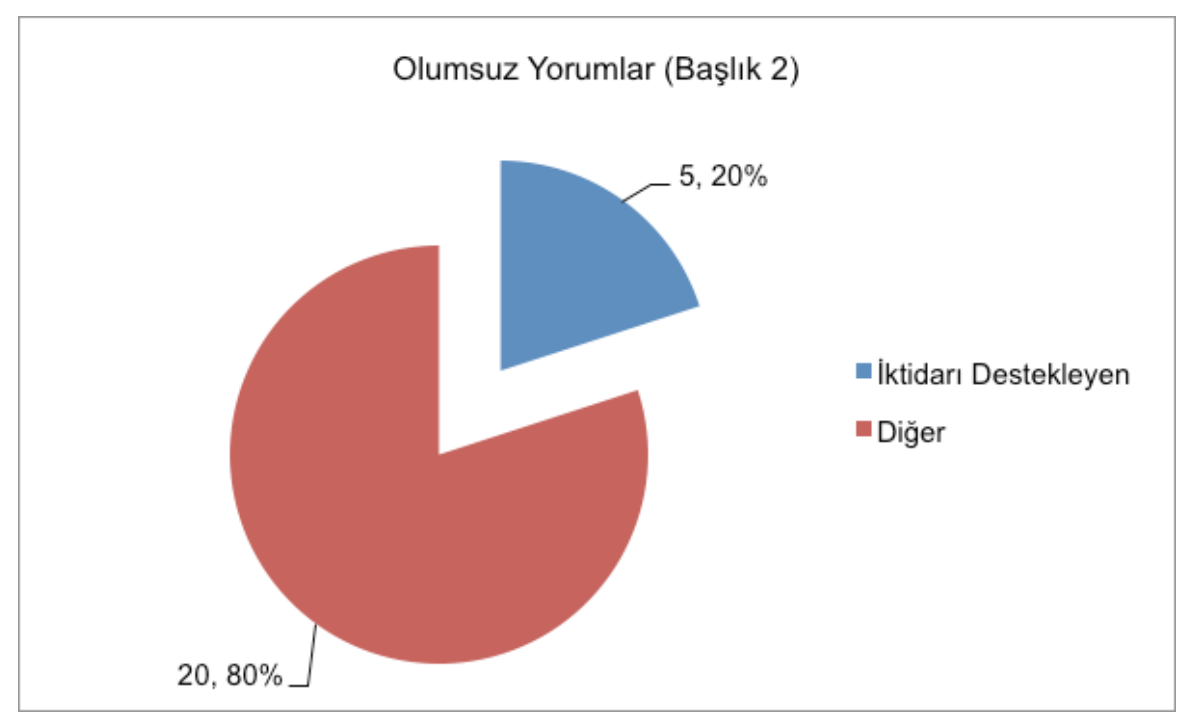

Yorumlar üzerine yapılan incelemeye göre yürüyüşü destekler nitelikteki yorumlar büyük bir yer kaplamaktadır. Bu da Ekşi Sözlük'te muhalif bir anlayışın hâkim olduğunu göstermektedir. Bu noktada Ekşi Sözlük'te farklı toplumsal grupların karşı karşıya geldiği ve farklı kolektif hafızaların bir arada bulunduğunu söylemek güçtür. Farklı görüşler olsa da daha çok homojen bir yapı görülmektedir. 
Burada Ekşi Sözlük'ün belli bir kültüre sahip, sanal bir topluluk olma özelliğinin ön plana çıktığı düşünülebilir. Bunun yanı sıra olumsuz yorumlar incelendiğinde bunların büyük bölümünün muhalefeti ve yürüyüşü eleştirdiği ancak iktidarı desteklemediği görülmektedir.

Kolektif hafıza açısından önemli olan hatırlatıcı ifadeler ise yine yorumlarla birlikte oluşturulmuştur. Güncel bir konudan bahsederken geçmişe referanslar verilmesi kolektif hafızanın canlı tutulması açısından önemlidir. Bu noktada kullanıcıların geçmişi referans alarak yorumlar yaptığı gözlemlenmiştir. İncelenen başlıklardaki geçmiş referanslarına bakıldığında 5 entry ve üzerinde referans gösterilmiş olaylar aşağıdaki tabloda gösterilmiştir.

Tablo 2. Enrtylerde Hatırlatılan/Hatıllanan Olaylar

\begin{tabular}{|l|l|l|}
\hline Entrylerde hatırlanan/hatıılatılan olaylar & $\begin{array}{l}\text { Entry Sayısı } \\
(1 . \text { Başık) }\end{array}$ & $\begin{array}{l}\text { Entry SayıSı } \\
(2 . \text { Başlık) }\end{array}$ \\
\hline 16 Nisan 2017 Anayasa Değişikliği Referandumu & 20 & 5 \\
\hline Gezi Hareketi (Haziran 2013) & 16 & 12 \\
\hline $\begin{array}{l}\text { Milletvekili dokunulmazlıklarının kaldıııması } \\
\text { (20 Mayıs 2016) }\end{array}$ & 10 & 2 \\
\hline 15 Temmuz 2016 Darbe Girişimi & 8 & 5 \\
\hline Geçmiş Seçimlerdeki AKP mitingleri & 0 & 8 \\
\hline HDP'li vekillerin tutuklanması (2017) & 7 & 0 \\
\hline $\begin{array}{l}\text { Geçmişteki yerel ve genel seçim sonuçları } \\
\text { (2010 sonrası) }\end{array}$ & 7 & 2 \\
\hline Cumhuriyet mitingleri (2007) & 1 & 5 \\
\hline
\end{tabular}

Yukarıdaki tabloya göre Ekşi Sözlük yazarlarının Adalet Yürüyüşü ve Mitingi ile ilgili olarak hatılladıkları ya da hatırlattıkları olayların başında 16 Nisan 2017'de gerçekleşen Anayasa Değişikliği Referandumu bulunmaktadır. Yürüyüşün açıklanması ve yürüyüş sürecini içeren ilk başlıkta bu göndermenin yoğun olmasının sebebi kullanıcıların CHP'nin tepki gösterme konusunda geç kaldığı ve referandum sonucuna güçlü bir muhalefetle itiraz etmesi gerektiğinin vurgulanmasıdır. CHP'nin yakın gelecekteki politik kararlarının eleştirildiği diğer konular da milletvekili dokunulmazlıklarının kaldırıması ve sonraki süreçte bununla bağlantılı olarak HDP'li vekillerin tutuklanma olaylarıdır. ${ }^{9}$ Iık başlıkta CHP'nin aldığı yürüyüş kararı geç bir karar olarak nitelenmiştir. Bu durum kullanıcılara CHP'nin geçmişte tepki göstermesini bekledikleri olayları ya da eleştirdikleri politikaları hatırlatmıştır. Her iki başlıkta da yakın geçmişte Türkiye'de yaşanan en önemli olaylardan biri olan 15 Temmuz Darbe Girişimi de hatırlanmıştır. İkinci başlığın yürüyüş sonucunda gerçekleşen miting ile ilgili olmasından dolayı Gezi Hareketi benzetmeleri, Cumhuriyet mitingleri benzetmeleri ve geçmişteki AKP mitingleri

9 ilk başlıkta 73 hatırlatıcı ifade içeren enrty'den 34'ü muhalif nitelikte olmasına karşın CHP'nin bu konulardaki politik tavrını eleştirmiştir. İkinci başlıkta ise bu sayı 45 hatırlatıcı enrty içerisinde $9^{\prime}$ dur. 
ile yapılan kıyaslamalar daha belirgindir. Sonuç olarak hatırlatıcı nitelik taşıyan entrylerde yakın geçmişe ait önemli olayların daha çok vurgulandığı görülmüştür.

Ekşi sözlük muhalif görüşlerin ağırlıkta olduğu bir ortamdır. Geçmiş referanslarla CHP eleştirilmiş olsa bile bu örneklerde iktidar yanlısı enrtylerin sayısı oldukça düşüktür. Geçmişe referans yapılan enrtylerdeki politik eğilime bakıldığında ilk başlıkta sadece 1 enrty iktidar yanlısı ifadeler içermektedir. Bu entryde cemaat eleştirisi yapılarak Ergenekon davaları, Miт tırları haberleri, 17 Aralık ve çözüm süreci hatırlanmıştır. İkinci başlıkta ise iktidar yanlısı 4 entry bulunmaktadır. Bu entrylerde Gezi Hareketi, 28 Şubat süreci, 27 Nisan 2007 Muhtırası, Cumhuriyet mitingleri ve bu dönemde cumhurbaşkanı seçimi konusunda mecliste çıkan sorunlar, AKP kapatma davası, geçmiş AKP mitingleri, 1998'deki türban eylemleri gibi geçmiş olaylar hatırlanmış ya da hatırlatılmıştır.

\section{Sonuç}

Bir topluluğun ortak deneyimlerine dayalı olarak oluşan kolektif hafıza kültürel metin ve unsurlar üzerinden geleceğe aktarılmaktadır. Bu noktada medya bir hafıza mekânı olarak hem kolektif hafızanın taşındığı hem de iktidar ve sermayenin yönlendirmesiyle inşa edildiği bir ortam olarak öne çıkmaktadır.

Yeni medya ile birlikte kolektif hafızanın taşınması, saklanması ve inşa edilmesi süreçleri önemli bir değişimden geçmiş, özellikle kullanıcının içerik üretimiyle birlikte bireyler kolektif hafızanın inşasına daha etkin bir şekilde katııma imkânı bulmuştur. Kullanıcının içerik üretimi ile birlikte bireysel tanıkıklar, yorumlar, görüşler kamusal olarak görünür hale gelmektedir. Bu bağlamda internet, bireysel ve kolektif hafızaların kayıt altına alındığı ve inşa edildiği bir ortam sunmaktadır. Bu bağlamda yeni medyada "kullanıcı üretimi" bir kolektif hafızanın inşa edildiği söylenebilir. Bu çalışmada da kullanıcının içerik üretiminin kolektif hafızanın inşa sürecini nasıl etkilediği anlaşımaya çalışılmıştır. Bu kapsamda Türkiye'de yakın geçmişte gerçekleşmiş bir olay olarak Adalet Yürüyüşü'nün Ekşi Sözlük'teki yansıması incelenerek "kullanıcı üretimi" kolektif hafızanın özellikleri anlaşılmaya çalışılmıştır.

Ekşi Sözlük güncel olayların, bireysel yorum ve görüşlerin yoğun olarak aktarıldığı bir ortam olarak kolektif hafızanın inşa edildiği ve kullanıcı üretimi içeriğe dayanan hafıza mekânlarından biridir. Bu internet sitesi gözlemlendiğinde, yeni medyanın kolektif hafıza üzerindeki avantajları ve dezavantajları somutlaşmaktadır. Yeni medyada çok miktarda bilgi olması, bu bilgi yığını içinde doğru bilgiye erişmeyi zorlaştırmaktadır. Ekşi Sözlük kapsamında yapılan analiz de her gün sitede yeni başlıklar açıldığını ve buna bağlı olarak yüksek düzeyde verinin sayfaya girildiğini göstermiştir. Bu kapsamda kolektif hafızanın inşa sürecinde çok fazla bilgi, yorum ve tanımlama şeklindeki içeriğin kullanıılar tarafından yazıldığı görülmektedir. Bu durum önemli bilgilerin "entry" yığınında kaybolmasına yol açabileceğinden kolektif hafıza açısından olumsuzluk içermektedir. Bu özellik okuyucuların ve belli bir konuda araştırma yapanların detaylı bir inceleme yapması gerekliliğini 
doğurmaktadır. Ekşi Sözlük'teki başlıkların tarih içererek oluşturulması ve site içerisinde arama yapılarak geçmiş başlıkların okunabilmesi ise yeni medyada kaydedilen kolektif hafıza açısından olumlu özellikleri olarak görülebilir.

Kolektif hafızanın inşasını incelerken Ekşi Sözlük'ün ticari kaygılar taşıyan bir yeni medya şirketi olduğunu da akılda bulundurmak gerekmektedir. Site reklam yayınlamakta sayfa yöneticileri ve kurucuları içerik üzerinde etkili olabilmektedir. Bu nedenle bazı durumlarda bazı başlıkların ve entrylerin silinebildiğini de unutmamak gerekir. Politik nedenlerle de içerik silinmesi ya da site erişiminin engellenmesi gibi durumlar da yaşanabilmektedir. Bu durum kolektif hafıza açısından olumsuz bir özelliktir.

Analizde görüldüğü gibi yeni medyada inşa edilen kolektif hafızanın en önemli özelliği yoruma dayalı içeriğine dayanıyor olmasıdır. Bu kapsamda kolektif hafızanın kullanıcıların süzgecinden geçerek inşa edildiği söylenebilir. Yorumların da ağırlıklı olarak belli bir eğilimde olduğu gözlemlenmiştir. Bu noktada farkı seslere yer verse de belli bir eğilim ağır basmaktadır. Burada da Ekşi Sözlük'ün belli bir kültüre, jargona sahip olan sanal bir topluluk olma özelliği ön plana çıkmaktadır.

Araştırmada geçmiş olayları hatırlatııı ifadelerin de içerik olarak Ekşi Sözlük'te yazıldığı görülmüştür. Entrylerdeki geçmiş referansları daha detaylı incelendiğinde kullanıcıların büyük bölümünün iktidarı desteklemediği, düzenlenen yürüyüşe olumlu yaklaşsalar da ana muhalefet partisini hatalı olduğunu düşündükleri noktalarda eleştirdikleri görülmüştür. CHP'nin politik kararlarının hatırlanmasında, incelenen örneğin CHP'nin düzenlemiş olduğu bir yürüyüş ve miting olması da etkili olmuştur.

Entrylerdeki geçmiş referanslarının çoğunluğunun yakın geçmişi hatırlattıkları görülmüştür. Geçmişe referans verilmesi kolektif hafızanın canlı tutulması açısından önemlidir. Bu tarz içerikler okuyucuların zihnini kolektif hafızayı oluşturan farklı bir olaya yönlendirmektedir. Bu kapsamda entrylerde hiperbağların da kullanıldığı ve okuyucuların farklı başlıklara, sayfalara, alternatif bilgi kayaklarına yönlendirilebildiği görülmüştür.

Adalet Yürüyüşü'nün Ekşi Sözlük'teki inşası, yeni medyada kullanıcı üretimi içerik üzerinden inşa edilen kolektif hafızanın özellikleri ve yapısı konusunda fikir vermektedir. Araştırma sonucuna göre bu şekilde oluşan kolektif hafıza kısa, parçalı, anlık bilgilere dayanmakta ve ağırlıklı olarak yorumlardan oluşmaktadır. Ayrıca inceleme kapsamında içerik üreten kullanıcıların yüksek düzeyde çeşitlilik gösterdiği, ancak içeriklerin kısa bir şekilde yazıldığı görülmüştür. Bu da bireylerin kolektif hafıza inşasına yüzeysel olarak dâhil olduklarını göstermektedir. Dolayısıyla bu tür ortamlarda bilinçli bir hafıza inşası olduğunu söylemek güçtür. Bu özellikler kolektif hafızanın geleceğe aktarıması açısından olumsuz olsa da farklı perspektiflerin, bireysel seslerin, kullanıcıların bakış açısının kaydedilmesi, iletilmesi ve alternatif bilgi kaynaklarının oluşabilmesi açısından önemli görülebilir. 
Internette inşa edilen kolektif hafıza yeni medyanın özelliklerinden etkilenmektedir. Yeni medyanın önemli bir olumsuz özelliği, kullanııların gerçek kimliklerinden ve gerçekleri söylediklerinden emin olunamamasıdır. Dijital içerik kolayca manipüle edilebilir, silinebilir veya değiştirilebilir. Bu özellik kolektif hafızayı zayıflatır. Yine de yeni medyanın bireylerin kendilerini ifade etmeleri ve içerik oluşturmaları için bir alan açması, alternatif bir kolektif hafızanın oluşması ve farklı seslerin duyulması açısından önemli görülebilir. Bu noktada insanların bir konuyu araştırırken farklı kaynaklarda arama yapması yukarıda sözü edilen sorunların farkında olarak eleştirel bir gözle içerikleri değerlendirmesi gerekmektedir. Bu konu da medya okuryazarlığı, dijital okuryazarlık gibi konularla ilişkili olup farklı bir çalışmada incelenebilir.

\section{Kaynakça}

Akgül, M., ve Kırlıdoğ, M. (2015). Internet Censorship in Turkey. Internet Policy Review, 4(2), 1-22.

Alternatif Bilişim Derneği. (2016). Türkiye'de Internet'in Durumu 2015 Raporu. Alternatif Bilişim Derneği. İstanbul: Alternatif Bilişim Derneği.

Assmann, J. (2001). Kültürel Bellek: Eski Yüksek Kültürde Yazı, Hatırlama ve Politik Kimlik. (A. Tekin, Çev.) İstanbul: Ayrıntı Yayınları.

Assmann, J. (2011). Communicative and Cultural Memory. P. Meusburger, M. Heffernan ve E. Wunder (Ed.), Cultural Memories: The Geographical Point of View içinde (15-27). London: Springer.

Barash, J. (2007). Belleğin Kaynakları. (Ş. Öztürk, Ed.) Cogito(50), 11-22.

Başaran Ince, G. (2010). Medya ve Toplumsal Hafıza. Kültür ve Iletişim, 13(1), 9-29.

Başaran Ince, G. (2014). Digital Culture, New Media and the Transformation of Collective Memory. iLETi-Ş-IM(21), 9-29.

Castells, M. (2005). Enformasyon Çağı: Ekonomi, Toplum ve Kültür (Cilt 1). (E. Kılıç, Çev.) İstanbul: İstanbul Bilgi Üniversitesi.

Castells, M. (2009). Communication Power. NewYork: Oxford University.

Donk, A. (2009). The Digitization of Memory: Blessing or Curse? A Communication Science Perspective. M. I. Technology (Dü.), Media in Transition Conference "MIT6: Stone and Papyrus, Storage and Transmission içinde, (1-17). Boston.

Durkheim, E. (1973). On Morality and Society (Selected Writings). (R. Bellah, Ed.) Chicago: The University of Chicago.

Fuchs, C. (2008). Internet and Society: Social Theory in The Information Age. NewYork: Routledge. 
Fuchs, C. (2010). Social Software and Web 2.0: Their Social Theory in The Information Age. S. Murugesan (Ed.), Handbook of Research on Web 2.0, 3.0, and X.0: Technologies, Business, and Social Applications içinde (764-789). Hershey: Information Science Reference.

Garde-Hansen, J. (2011). Media and Memory. Edinburgh: Edinburgh University Press.

Garde-Hansen, J., Hoskins, A., ve Reading, A. (2009). Introduction. J. GardeHansen, A. Hoskins, \& A. Reading (Ed.), Save As... Digital Memories içinde (121). New York: Palgrave MacMillan.

Halbwachs, M. (1980). The Collective Memory. (F. Ditter, Jr., \& V. Ditter, Çev.) New York: Harper Colophon Books.

Halbwachs, M. (1992). On Collective Memory. L. Coser, (Ed.), (L. Coser, Çev.) Chicago: The University of Chicago.

Hand, M. (2014). Digitization and Memory: Reserching Practices of Adaptation to Visual and Textual Data in Everyday Life. M. Hand, \& S. Hillyard (Ed.), Big Data? Qualitative Approches to Visual and Textual Data in Everyday Life içinde (205227). Bingley: Emerald Group Publishing.

Henkoğlu, T., ve Yılmaz , B. (2013). İnternet Erişim Özgürlüğünün Kısıtlanması: Türkiye Üzerine Bir Değerlendirme. Bilgi Dünyası, 14(2), 215-239.

Hoskins, A. (2009a). Digital Network Memory. A. Erll, \& A. Nünning (Ed.). Media and Cultural Memory içinde (91-106). Berlin: Walter de Gruyer.

Hoskins, A. (2009b). The Mediatisation of Memory. J. Garde-Hansen, A. Hoskins, \& A. Reading (Ed.). Save As... Digital Memories içinde (27-43). New York: Palgrave MacMillan.

Hoskins, A. (2011). 7/7 and Connective Memory: Interactional Trajectories of Remembring in Post-scarcity Culture. Memory Studies, 4(3), 269-280.

Hoskins, A. (2013). The End of Decay Time. Memory Studies, 6(4), 387-389.

Huyssen, A. (2003). Present Pasts: Urban Palimpsets and the Politics of Memory. California: Stanford University.

Inceoğlu, Y., \& Çoban, S. (2015). Sokak ve Dijital Aktivizm: Eylemin Sokaktan Siber Uzaya Taşınması ya da Vice Versa. Y. İnceoğlu, \& S. Çoban (Ed.). İnternet ve Sokak: Sosyal Medyada Dijital Aktivizm ve Eylem içinde (19-72). İstanbul: Ayrıntı.

Jenkins, H. (2001). Digital Renaissance: Convergence? I Diverge. Technology Review, 93. Erişim: 26 Aralık 2012, http://phase1.nccr-trade.org/ images/stories/ jenkins_ convergence_optional.pdf.

Le Han, E. (2016). Micro-blogging Memories: Weibo and Collective Remembering in Contemporary China. Springer.

Manovich, L. (2001). The Language of New Media. Massachusetts: MIT. 
Marcuse, H. (1968). Tek Boyutlu Insan: Ileri Endüstriyel Toplumun Ideolojisi Üzerinde Inceleme. (S. Çağan, Çev.) İstanbul: May.

Mayer-Schönberger, V. (2011). Delete: The Virtue of Forgetting in the Digital Age (4 b.). New Jersey: Princeton University.

Moyo, L. (2009). The Digital Divide: Scarcity, Inequality and Conflict. G. Creeber, \& R. Martin içinde, Digital Cultures: Understanding New Media (s. 122-130). New York: Open University.

Nora, P. (2006). Hafıza Mekanları. (M. Özcan, Çev.) Ankara: Dost.

Olick, J. (2008). From Collective Memory to the Sociology of Mnemonic Practices and Products. A. Erll, \& A. Nünning (Ed.). Cultural Memory Studies: An International and Interdisciplinary Handbook içinde (151-161). Berlin: Walter de Gruyter.

Olick, J. (2014). Kolektif Bellek: İki Farklı Kültür. (M. Güneşdoğmuş, Ed.) Moment Dergi, 1(2), 175-211.

Özhan Koçak, D. (2017). Collective Memory and Digital Practices of Rememberance. H. Friese, G. Rebane, M. Nolden, \& M. Schreiter (Ed.). Handbuch Soziale Praktiken und Digitale Alltagswelten içinde (1-13). Wiesbaden: Springer.

Özhan Koçak, D., \& Koçak, O. (2012). Digitalized Memory and the Loss of Social Memory. S. Sak (Ed.). Remembering Digitally içinde (3-14). Oxford: InterDisciplinary.

Reading, A. (2009). Memobilia: The Mobile Phone and the Emergence of Wearable Memories. J. Garde-Hansen, A. Hoskins, \& A. Reading (Ed.). Save As... Digital Memories içinde (81-95). New York: Palgrave MacMillan.

Schudson, M. (2007). Kolektif Bellekte Çarpıtma Dinamikleri. (B. Kovulmaz, Ed.) Cogito(50), 179-199.

Simpson, G. (2005). Editor's Preface. E. Durkheim, \& G. Simpson (Ed.). (J. Spaulding, \& G. Simpson, Çev.) Suicide: A Study in Sociology içinde (IX-XII). London: Routledge.

Türkiye'de Wikipedia'ya Erişim Engeli. (2017, Nisan 29). Erişim: 25 Nisan 2018, https://www.bbc.com/turkce: https://www.bbc.com/turkce/haberlerturkiye-39718562.

van Dijck, J. (2007). Mediated Memories in the Digital Age. California: Stanford University.

van Dijck, J. (2009). Users Like You? Theorizing Agency in User-Generated Content. Media Culture \& Society, 31(4), 41-58.

van Dijck, J. (2010). Flickr and the Culture of Connectivity: Shaing Views, Expriences, Memories. Memory Studies, 4(4), 401-415. 
